\title{
ARTICLE \\ The Characterization of Pre-insolvency Proceedings in Private International Law
}

\author{
Irit Mevorach ${ }^{3} \cdot$ Adrian Walters $^{1,2}$
}

Published online: 26 February 2020

(c) The Author(s) 2020

\begin{abstract}
The decade since the financial crisis has witnessed a proliferation of various 'light touch' financial restructuring techniques in the form of so-called pre-insolvency proceedings. These proceedings inhabit a space on the spectrum of insolvency and restructuring law, somewhere between a pure contractual workout, the domain of contract law, and a formal insolvency or rehabilitation proceeding, the domain of insolvency law. While, to date, international insolvency instruments have tended to define insolvency proceedings quite expansively, discussion of the cross-border implications of pre-insolvency proceedings has barely begun. The question is whether pre-insolvency proceedings should qualify as proceedings related to insolvency for the purpose of private international law characterization. The risk is overinclusivity of cross-border insolvency law, which, where it is based on universality and unity, might defeat contractual expectations. This article argues, however, that we should be slow to exclude pre-insolvency proceedings from cross-border insolvency law: these proceedings are initiated in the zone of insolvency, their effectiveness depends on a statutory mandate and not purely on private ordering, they interact and intersect with formal proceedings, and can benefit from the unique system developed by cross-border insolvency law. We suggest, though, that modified universalism (the leading norm of cross-border insolvency) and international insolvency instruments, should, and are able to, adjust to the peculiarities of preinsolvency proceedings to address concerns about inclusivity and accommodate preinsolvency proceedings adequately.
\end{abstract}

Keywords Insolvency $\cdot$ Restructuring $\cdot$ Pre-insolvency proceedings $\cdot$ Cross-border insolvency $\cdot$ Private international law $\cdot$ Modified universalism

All uniform resource locators cited in footnotes were live on 4 February 2020.

Adrian Walters

awalters@kentlaw.iit.edu

Extended author information available on the last page of the article 


\section{Introduction}

Insolvency is typically excluded from international instruments harmonizing the private international law of commercial and civil law matters. ${ }^{1}$ It is a 'unique' subsystem of commercial law, linked to issues of public interest and aiming to promote a fair process taking account of interests of multiple groups of stakeholders, to maximize value, minimize waste, and, enable rescue of viable businesses. Thus, international insolvency law (or 'cross-border insolvency') is developing as a sui generis system of private international law for transnational insolvency, which aims to achieve the goals of insolvency in cross-border cases. ${ }^{2}$ Predominantly based on the norm of modified universalism, ${ }^{3}$ this emerging cross-border insolvency system prescribes efficient levels of centralization of proceedings, recognized and assisted by foreign authorities, to maximize value and enable business rescue, considering all relevant stakeholders wherever located. This special system seeks to transcend domestic private international law rules to provide a harmonized framework for international insolvencies.

The decade since the financial crisis has witnessed, however, a significant shift from bank to capital market financing of large corporate borrowers that has led to profound changes in the market for resolution of corporate financial distress ${ }^{4}$ notably the emergence of 'light touch' formal financial (balance sheet) restructuring techniques. ${ }^{5}$ Policymakers, especially in the European Union, have responded to market developments by embarking on an aggressive new phase of corporate rescue oriented legislative endeavour that focuses on so-called pre-insolvency or preventive insolvency proceedings. ${ }^{6}$

\footnotetext{
${ }^{1}$ Insolvency is, for example, excluded from the Hague Convention on the Recognition and Enforcement of Foreign Judgments of 2 July 2019 (see Art. 2(1)(e); https://www.hcch.net/en/instruments/convention s/full-text/?cid=137); Bankruptcy judgments are excluded from the EU regime for enforcement of judgments in civil and commercial matters (in the EU, jurisdiction, recognition, and enforcement of judgments in civil and commercial matters, excluding bankruptcy, is subject to the Brussels I Regulation; Regulation (EU) No. 1215/2012 of the European Parliament and of the Council of 12 December 2012 on the jurisdiction and the recognition and enforcement of judgments in civil and commercial matters [2012] OJ L351/1). Bankruptcy matters were also excluded from the Hague Convention of 1 February 1971 on the Recognition and Enforcement of Foreign Judgments in Civil and Commercial Matters and from the Convention of 30 June 2005 on Choice of Court Agreements.

${ }^{2}$ See also Fletcher (2005), p 15, who proposed that cross-border insolvency should be based on 'internationalist' principles and construct 'rules of private international law that are in harmony with the realities of such cross-border activity'. Cf. Rubin v. Eurofinance SA [2012] UKSC 46, [2013] 1 AC 236, [102][105] (Lord Collins) declining to accept a sui generis characterization of transaction avoidance proceedings.

${ }^{3}$ See generally, Westbrook (2000); Mevorach (2018a), ch. 1.

${ }^{4}$ See Paterson (2016), p 701.

${ }^{5}$ See e.g. the English Scheme of Arrangement in Part 26 of the Companies Act 2006, the Spanish Homologated Refinancing Agreement introduced in 2015, or the Romanian Preventive Concordat proceedings, included in a reformed insolvency law (Law 85/2014 on insolvency prevention procedures and insolvency). See also generally INSOL Europe (2018); Stanghellini et al. (2018), and the discussion of the US Chapter 11 and its influence globally, in Sect. 2 below.

${ }^{6}$ Directive (EU) 2019/1023 of the European Parliament and of the Council of 20 June 2019 on preventive restructuring frameworks, on discharge of debt and disqualifications, and on measures to increase the efficiency of procedures concerning restructuring, insolvency and discharge of debt, and amending
} 
This current vogue for pre-insolvency proceedings is the latest phase of a global effort to fashion a comprehensive range of debt resolution tools for use at various stages of what accountants sometimes refer to as the demise curve ${ }^{7}$ of the corporate life cycle. In many systems, until relatively recently, the only viable choice for debtors and creditors were at the extremes: either a private, informal, out-of-court workout - in other words a contract between the debtor and creditors, and the creditors inter se, requiring unanimity among creditors for it to become binding-or a formal liquidation in which creditors, aided by an officeholder (be that a trustee, liquidator, or receiver), take control of and liquidate the assets before dividing the proceeds among themselves. ${ }^{8}$ Recognition, however, has grown of the importance of value maximization at whichever point on the demise curve the formal intervention occurs. As a result, business insolvency systems have evolved to offer a spectrum of possibilities - including formal reorganization or rehabilitation proceedings at intermediate points on the spectrum between the extremes-with some facility to convert from one procedure to another, or to combine various procedures, depending on the circumstances.

Since the Asian financial crisis of the late-1990s, international institutions such as the IMF, the World Bank, and UNCITRAL have actively championed reforms ${ }^{9}$ that provide formal rehabilitation alternatives to a contractual workout or a liquidation, incorporating features such as a stay on creditor enforcement to prevent runs on the assets, and mechanisms for the authorization of post-commencement financing, the proposal, approval and court confirmation of formal plans of reorganization, and the conversion of rehabilitation to liquidation proceedings in the event that the debtor

Footnote 6 (continued)

Directive (EU) 2017/1132 [2019] OJ L172/18. For legislative history see EU Commission, Proposal for a Directive of the European Parliament and of the Council on preventive restructuring frameworks, second chance and measures to increase the efficiency of restructuring, insolvency and discharge procedures COM (2016) 723 final, 2016/0359 (COD) ('Commission Proposal'). The EU Council adopted its initial position on the proposed Directive on 11 October 2018 and produced a compromise text: see EU Council 12536/18 ('Council Position'). See also European Parliament legislative resolution of 28 March 2019 on the proposal for a directive of the European Parliament and of the Council on preventive restructuring frameworks, second chance and measures to increase the efficiency of restructuring, insolvency and discharge procedures and amending Directive 2012/30/EU (P8_TA-PROV (2019) 0321). For commentary on the text of the Directive in the form originally proposed by the EU Commission see McCormack (2017); Tollenaar (2017). It should be noted, though, that this initiative, although contemplating tools that may in practice be used by large entities was primarily aimed at addressing the problem of small and medium-sized enterprises in distress. See e.g. Commission Proposal, p 19 (aims stated to include reduction in barriers to cross-border credit to SMEs and increased access for SMEs to early warning tools).

7 See e.g. Sutton and Setchim (2014), p 405.

8 See Westbrook et al. (2010), pp 126-129.

9 See International Monetary Fund, Orderly \& Effective Insolvency Procedures (1999), http://www. imf.org/external/pubs/ft/orderly; The World Bank, Principles and Guidelines for Effective Insolvency and Creditor Rights Systems (Revised 2015), http://www.worldbank.org/en/topic/financialsector/brief/ the-world-bank-principles-for-effective-insolvency-and-creditor-rights; UNCITRAL Legislative Guide on Insolvency Law, Parts One and Two (United Nations 2005), http://www.uncitral.org/uncitral/en/uncit ral_texts/insolvency/2004Guide.html. 
fails to have a plan confirmed. ${ }^{10}$ These institutions now regard insolvency systems offering a broader spectrum of informal and formal debt resolution procedures as critical in promoting access to affordable credit and financial stability. ${ }^{11}$ Chapter 11 of the US Bankruptcy Code has been particularly influential in this process ${ }^{12}$ and has been almost elevated to the status of a global template for formal reorganization law, ${ }^{13}$ although international standards have been designed flexibly to accommodate different legal systems at varying stages of economic development.

Pre-insolvency proceedings, at their core, inhabit a space on the spectrum somewhere between a pure contractual workout and a formal insolvency or rehabilitation proceeding. They are restructuring proceedings that corporate debtors can access before they become insolvent with the aim of avoiding insolvency. They entail a surgical debt restructuring and an early intervention at the first signs of distress, concentrating on financial creditors rather than creditors of the operating business, permitting no, or limited, court involvement, avoiding stigma and reputational damage. Such proceedings may preserve value better than later-stage intervention through formal insolvency proceedings that implicate all stakeholders, and almost invariably result in distressed asset sales of one form (liquidation, break up) or another (prepack designed to achieve a going concern, or at least a 'better than liquidation' outcome). ${ }^{14}$ Pre-insolvency proceedings are typically designed for use by debtors whose businesses are profitable, in that operating revenues exceed operating expenses, but whose balance sheets are overleveraged with the consequence that they will not be sufficiently profitable to repay their financial creditors as these creditors' loans mature. They usually offer the prospect of effective early intervention in situations where contractual workouts are not possible because there is deadlock among creditors, by providing voting mechanisms that enable assenting majorities of creditors to bind dissenting 'holdout' creditors to the terms of a restructuring deal. ${ }^{15}$

Across the spectrum, insolvency and restructuring law provides a comprehensive and dynamic series of ex post interventions. Viable companies with overleveraged capital structures can access deadlock resolution procedures and thus overcome

\footnotetext{
10 See e.g. UNCITRAL Legislative Guide on Insolvency Law, Part Two (United Nations 2005), pp 83-103, 113-119, 209-238.

11 See e.g. The World Bank, Principles and Guidelines for Effective Insolvency and Creditor Rights Systems (Revised 2015), iii ('The ICR Principles support a sound insolvency and creditor/debtor rights [...] framework, which is crucial to promoting access to finance because it provides a predictable, transparent, and efficient framework to resolve debts in the context of business distress or failure [...]. At the same time, access to credit has to be considered in the context of the overwhelming need for macro-financial stability. In the wake of the global financial crisis, the international community has a renewed interest in ensuring financial systems remain as sound and resilient as possible.').

12 In part because of the outsized influence of the United States on the Bretton-Woods institutions. See Woods (2003).

13 For example, Singapore's recent reforms to its corporate insolvency and restructuring laws in the Singapore Companies (Amendment) Act 2017 were heavily influenced by US chapter 11. See further Wee (2017); McCormack and Wan (2018).

14 See Westbrook et al. (2010), pp 124-125.

15 The existence of such easy-to-access, formal deadlock resolution procedures may conceivably promote informal workouts by facilitating bargaining in the shadow of the law.
} 
obstacles to an informal workout. ${ }^{16}$ The businesses of companies that are more deeply distressed can be salvaged, and returns to creditors maximized, by means of a sale for the best price reasonably obtainable ${ }^{17}$ - be that at going concern value, 'better than liquidation' value or some point in between. Companies can attempt a restructuring and transition to a formal insolvency or rehabilitation proceeding to implement an asset sale if the restructuring is unsuccessful. Inevitably, though, there is blurriness in domestic legislative offerings - in other words, there are plenty of examples of hybrid proceedings that can function both as pre-insolvency restructuring proceedings and as formal rehabilitation proceedings that insolvent debtors and their creditors can use to salvage value at points further down the demise curve.

As capital structures have come to be dominated by secured credit, urgent questions have arisen about the impact of secured creditor control on the choice between a restructuring or a sale and, where a sale is pursued, the timing of the sale. ${ }^{18}$ The primary sorting question-which companies should be restructured and which companies should have their assets sold-thus looms large and justifies a clear analytic distinction of the kind that Sarah Paterson draws between, on the one hand, proceedings aimed at rewriting the bargain between the debtor, its finance creditors and shareholders, and, on the other hand, formal insolvency and rehabilitation proceedings aimed at realizing the assets. ${ }^{19}$ But while insolvency and restructuring law deploys a range of different tools-some that pursue a restructuring outcome, some that pursue a sale outcome, some that function as hybrids-altogether these processes nevertheless amount to a comprehensive, unified body of law. That law addresses coordination problems for which private ordering alone does not provide effective solutions, with the goal of maximizing enterprise value across a sliding scale of situations ranging from anticipated to actual distress.

Initiatives such as the EU's Directive on Preventive Restructuring Frameworks ('the Directive') ${ }^{20}$ are concerned with harmonization of domestic laws. But as many large restructurings transcend national boundaries, the purpose of our article is to consider the treatment of pre-insolvency proceedings in private international law. While, to date, cross-border insolvency instruments have tended to define insolvency proceedings quite expansively, discussion of the cross-border implications of preinsolvency proceedings - and, in particular, the normative case for treating them

\footnotetext{
16 Paterson (2016), pp 702, 717 et seq.

17 Ibid.

18 The main concern is that secured creditors are biased in favour of expedited sales free and clear of creditor claims through mechanisms such as 11 USC 363 that deprive junior creditors of the safeguards of a full reorganization plan process and the ability to share in downstream going concern value that a delayed sale or restructuring might otherwise have generated. See e.g. American Bankruptcy Institute (2014), pp 83-87, 137-138, 201-204; Jacoby and Janger (2014); Jacoby (2018); Walters (2015), pp 543, 544-546. A competing concern is that systems biased towards preventive restructuring incentivize 'out of the money' junior creditors to press for restructuring of firms that should be liquidated. See e.g. Eidenmüller (2018b).

19 Paterson (2016), p 702.

20 See n. 6 above.
} 
under the same umbrella of formal insolvency proceedings in private international law-is only just beginning. ${ }^{21}$

This article first maps the contours of pre-insolvency proceedings (Sect. 2) and reviews how insolvency and pre-insolvency proceedings are treated in current crossborder insolvency law (Sect. 3). It then seeks to contribute to the normative discussion. Section 4 considers whether pre-insolvency proceedings should (or should continue to) be characterized as related to insolvency and be governed by the leading specialized cross-border insolvency instruments and by the norm of modified universalism. The risk is over-inclusivity of cross-border insolvency law, which, where it is based on universality and unity, might defeat contractual expectations. Thus, the alternative is to treat pre-insolvency proceedings as 'contract like' for the purpose of private international law characterization. However, we advance reasons why, in our view, we should be slow to exclude pre-insolvency proceedings from cross-border insolvency law. At stake in the normative debate is the availability (or otherwise) of the tools and norms of cross-border insolvency law-foreign recognition, expansive foreign court relief, and international cooperation, coordination, and communication between courts and other actors (aspects of the overarching norm of modified universalism) - to assist and protect pre-insolvency proceedings overseas. At a conceptual level, we doubt whether legislatively mandated or 'statesupplied' 22 deadlock resolution mechanisms, can properly be analogized for private international law purposes to consensual contract modifications. At a practical level, foreign court recognition, relief, and cooperation provide a necessary antidote to overseas manoeuvres by holdout creditors and are mechanisms that accommodate hybridity while also disfavouring procedural fragmentation. However, we do not see the 'contract' or 'insolvency' question as purely binary. Instead, we proceed to argue in Sect. 5 that cross-border insolvency law's dominant norm-modified universalism-is sufficiently flexible that it can evolve to accommodate the peculiarities of pre-insolvency proceedings successfully. Accordingly, while we suggest that crossborder insolvency law needs to be flexible, we see no compelling reason to change the current course or reinvent the wheel.

\section{Pre-insolvency Proceedings: Mapping the Contours}

This section identifies the main features and characteristics of pre-insolvency proceedings. It mainly draws on the influential chapter 11 of the US Bankruptcy Code and on the Directive. It contends that pre-insolvency proceedings have certain core characteristics but that, rather than necessarily standing alone, they may nest within broader, hybrid, multi-purpose proceedings — something akin to a matryoshka doll where a smaller figure nests inside a larger figure. This pliable nature of pre-insolvency proceedings has important implications for the decision how to treat these proceedings in international cases.

\footnotetext{
21 For two recent important contributions see Eidenmüller (2018a); Madaus (2018).

22 Eidenmüller and van Zwieten (2015), p 626.
} 
The aim of the Directive is 'to establish a common EU-wide framework to ensure effective restructuring, second chance and efficient procedures both at national and cross-border level'. ${ }^{23}$ The Directive builds on an earlier Recommendation that invited member states to introduce 'effective pre-insolvency procedures to help viable debtors to restructure and thus avoid insolvency'. ${ }^{24}$ From these pronouncements we can discern the first three core characteristics of pre-insolvency proceedings. First, they are formal in the sense that their effectiveness depends on a statutory mandate and not purely on private ordering. Second, they are primarily debt restructuring proceedings rather than proceedings for realizing assets and distributing proceeds, albeit, asset disposal may be contemplated as part of the restructuring. ${ }^{25}$ Third, they are proceedings that are available to debtor firms before they are factually insolvent-in other words, before their financial condition has deteriorated so deeply that they meet the statutory predicates (insolvency on a cash-flow and/or balance sheet basis) — that are thresholds to entry into formal insolvency or rehabilitation proceedings in many legal systems. ${ }^{26} \mathrm{~A}$ fourth core characteristic that relates to the third is that pre-insolvency proceedings may be debtor-in-possession proceedings - entry into the proceedings might not result in the replacement of the debtor's incumbent management by an officeholder such as an administrator or a liquidator. Thus, there is a positive incentive for managers to use pre-insolvency proceedings with this characteristic to address anticipated difficulties at an early stage because they will not lose control by doing so. ${ }^{27}$ Taking these four core characteristics as a whole, it is apt to describe pre-insolvency proceedings as 'a legal framework that allows firms to readjust their capital structure well before they are in fact insolvent'. 28

Pre-insolvency proceedings are thus designed to provide economically viable firms with a formal mechanism through which they can deleverage their balance

\footnotetext{
23 The legal basis of the proposal is the removal of obstacles to the functioning of the single market that raise financing costs for European firms. The Commission contends that an efficient, harmonized preventive restructuring framework will increase lender recovery rates, reduce the volume of non-performing loans held by financial institutions, and thus increase access to cheap capital on a pan-European basis: Commission Proposal (n. 6), pp 2-9, 12-15; Eidenmüller (2017), p 277 et seq.

24 Commission Proposal (n. 6), p 7. The EU Commission concluded that the adoption of the Recommendation in 2016 had 'not led to the desired impact in terms of consistent changes across all Member States': Ibid., p 8. Hence, the move towards more aggressive minimum standards harmonization in the form of a Directive.

25 Directive (n. 6), Art. 2(1) (defining 'restructuring' as 'measures aimed at restructuring the debtor's business that include changing the composition, conditions or structure of a debtor's assets and liabilities or any other part of the debtor's capital structure, such as sales of assets or parts of the business and, where so provided by national law, the sale of the business as a going concern, as well as any necessary operational changes, or a combination of those elements').

26 Westbrook et al. (2010), pp 65-68. See also Gurrea-Martínez (2018).

27 Corporate and insolvency laws may also create negative incentives to early voluntary formal intervention in the form of directors' liability provisions. See further Westbrook et al. (2010), pp 53-60; UNCITRAL Legislative Guide on Insolvency Law, Part Four: Directors' Obligations in the Period Approaching Insolvency (United Nations 2013). The goal of this combination of sticks (liability) and carrots (access to a debtor-in-possession restructuring proceeding) is to discourage managers from burying their heads in the sand.

${ }^{28}$ Eidenmüller (2017), p 274.
} 
sheets by renegotiating and concluding a new deal with their principal financial creditors on more favourable terms. The deal may involve one or more of a variety of refinancing techniques such as extended loan maturities (meaning that debt can be repaid later), reduced interest payments, reduced payments of principal indebtedness (commonly referred to as debt write-downs or 'haircuts') or agreements to exchange debt for equity (which have the combined effect of reducing principal indebtedness and reducing debt service costs in return for creditors sharing future 'upside' with owners). ${ }^{29}$ When distress is on the horizon, it makes sense for firms to try to renegotiate with their financial creditors before the debt matures or accelerates because contractual events of default in the finance documents are triggered.

The renegotiation has traditionally taken the form of an out-of-court workout ${ }^{30}$ in which the parties agree by contract to modify the terms of the existing debt or exchange it for fresh, less expensive, obligations. But workouts require unanimous consent or, where there is a collective action clause in the inter-creditor agreement that forms part of the original financing package, the consent of a prescribed supermajority of creditors. As such, while they can be successful, they are prone to holdout problems - creditors blocking the deal and using leverage to extract additional benefits for themselves - and 'free rider' problems - creditors who decline to participate, so that they are not bound by the workout terms, and yet who enjoy the prospect of full payment because concessions made by other creditors improve the debtor's financial health. ${ }^{31}$ The market has devised partial solutions, such as collective action clauses, exit consents, and consent fees, that go some way to addressing these coordination problems. ${ }^{32}$ However, to ensure that holdout and free rider problems can be overcome decisively, formal restructuring alternatives are required to protect the debtor against the disruptive threat of premature enforcement ${ }^{33}$ and to bind all creditors, including dissenters, to the terms of the restructuring deal. Preinsolvency proceedings therefore mirror workouts in important respects. They provide a framework that facilitates 'structured bargaining, ${ }^{34}$ over new financing terms between the debtor's managers and creditors prior to insolvency. They also permit, through a combination of deadlock resolution voting mechanisms and formal confirmation by a court or administrative authority, the imposition of majority-approved

\footnotetext{
${ }^{29}$ On the trend in post-crisis debt for equity swaps in the UK restructuring market see Paterson (2017), pp 611-612.

30 See generally Westbrook et al. (2010), ch. 5.

31 See e.g. Antonoff (2013); Eidenmüller and van Zwieten (2015).

32 For judicial consideration of consent fees, see e.g. Azevedo v. IMCOPA-Importacao, Exportaacao e Industria de Oleos Ltda [2012] EWHC 1849 (Comm) (Hamblen J). For judicial consideration of exit consents, see e.g. Assénagon Asset Management SA v. Irish Bank Resolution Corpn Ltd [2012] EWHC 2090 (Ch), [2013] 1 All ER 495 (Briggs J).

33 Though as Sarah Paterson has demonstrated, there is commonly a functional stay in a financial restructuring arising from a combination of contractual provisions that collectivize enforcement in the event of actual or potential default, stakeholder incentives, and the liquidity offered by distressed debt markets, which provide an exit route for financial creditors who can crystallize their losses without resorting to enforcement. See Paterson (2016), pp 713-714.

34 Eidenmüller (2017), pp 280, 289.
} 
restructuring deals on dissenting or non-participating minorities in a manner that overcomes the potential obstacles to a successful workout.

Chapter 11 of the United States Bankruptcy Code has been influential in the development of pre-insolvency proceedings globally. ${ }^{35}$ While, it is natural to think of chapter 11 as an insolvency proceeding, it was designed to promote restructuring by encouraging firm managers to negotiate and confirm a plan of reorganization under bankruptcy court oversight ${ }^{36}$ within the shelter provided by a statutory moratorium - the automatic stay. ${ }^{37}$ Firms filing voluntarily can access chapter $11-\mathrm{a}$ debtor-in-possession proceeding ${ }^{38}$ — without having to establish that they are factually insolvent. ${ }^{39}$ Managers control the direction of the case subject to bankruptcy court oversight and other institutional constraints. For example, the debtor-in-possession has a 120-day exclusivity period during which it-and it alone-can file a draft plan of reorganization, ${ }^{40}$ and it remains free to continue running the business in the ordinary course without the need for court approval of its day-to-day operations. $^{41}$

Moreover, chapter 11 contains elaborate mechanisms for deadlock resolution pursuant to which a plan of reorganization can be imposed on dissenting stakeholders through a mechanism known as 'whole class cramdown' as long as at least one impaired class votes in favour ${ }^{42}$ and the plan meets various statutory requirements, including requirements that the plan is feasible, ${ }^{43}$ does not unfairly discriminate, and

35 11 USC ss. 1101-1174.
36 Comparatists tend to exaggerate the extent of court oversight in the American system. See e.g. Baird
(2004), p 92 ('[The judge] acts only when a party files a motion or makes an objection. Negotiations
remain the lifeblood of bankruptcy, and practices evolve out of view to the bankruptcy judge'). That said,
nuanced empirical studies such as Jacoby (2015) have demonstrated that bankruptcy judges do employ active case management techniques in varying degrees in chapter 11 cases.

37 Which arises automatically on filing: 11 USC s. 362.

38 The debtor-in-possession can be displaced by a trustee on a showing of cause (including e.g. fraud, dishonesty, incompetence, or gross mismanagement): 11 USC 1104(a). Such appointments are rare.

39 Debtor eligibility is defined by 11 USC s. 109(a), (b), (d). 11 USC s. 301 provides that eligible debtors can commence a voluntary case by filing a bankruptcy petition with the court. There is no insolvency requirement. Instead, there is a power to dismiss a chapter 11 case for 'cause' under s. 1112(b) which has been used to fashion a 'bad faith filing' dismissal standard designed to flush out cases that lack a valid reorganizational purpose. See e.g. In re SGL Carbon Corporation 200 F 3d 154 (3rd Cir 1999); In re Integrated Telecom Express, Inc 384 F 3d 108 (3rd Cir 2004).

4011 USC s. 1121(b).

41 Court approval is required if the debtor-in-possession wishes to use, sell, or lease estate property other than in the ordinary course of business. Court approval is also needed before the debtor-in-possession can use, sell, or lease cash collateral. See 11 USC s. 363(b)(1), (c)(2).

42 The claims of affected stakeholders are divided into classes for purposes of treatment and voting: 11 USC s. 1122(a). Impaired classes - that is classes whose proposed plan treatment is inferior in some respect to their expected treatment outside of chapter $11-$ get to vote on the plan and if a majority in number of claims comprising two-thirds in amount in each class votes in favour, the plan is accepted: 11 USC ss. 1124, 1126(c). A class of claims is a creditor class. A class of interests-that is, a class of equity holders-accepts a plan if the holders of two-thirds in amount of the interests votes in favour. See 11 USC s. 1126(d).

43 The so-called feasibility requirement in 11 USC s. 1129(a)(11) requires a plan proponent to demonstrate by a preponderance of evidence that confirmation of the plan is not likely to be followed by the liquidation, or need for further financial reorganization, of the debtor or any successor to the debtor under the plan, unless such liquidation or reorganization is proposed in the plan. 
is fair and equitable in its treatment of dissenting classes. The court's confirmation of the plan is the source of its legally binding effects. It operates to discharge the firm's pre-bankruptcy obligations and replace them with new obligations under the plan. ${ }^{44}$

On paper, then, the chapter 11 model blends debtor-in-possession and low-barrier-to-entry features. It is designed to encourage early and easy access. It provides a statutory moratorium, plan voting, and confirmation mechanisms aimed at curbing opportunistic creditor behavior. As originally conceived, it is biased towards restructuring rather than asset sales ${ }^{45}$ and includes safeguards designed to protect dissenting minorities in the plan voting and confirmation process, and to balance the interests of creditors who would prefer to crystallize their loss rather than wait for their money. ${ }^{46}$

In truth, chapter 11 is a hybrid of a pre-insolvency restructuring proceeding and a formal rehabilitation procedure. Indeed, as financial markets have changed over time, ${ }^{47}$ and as practice has evolved in response, chapter 11 has come to function as a multi-purpose 'one-stop' shop. As well as wholesale reorganizations implicating all stakeholders (finance creditors, trade creditors, tort creditors) that may incorporate operational restructuring (i.e. changes to the business model) and extensive refinancing - chapter 11's original raison d'etre-it comfortably accommodates pre-packaged or pre-arranged financial restructurings, approximating to workouts. ${ }^{48}$ This type of 'skinny' restructuring, which is more limited in scope than a wholesale reorganization, affects only the finance creditors and often leaves the trade creditors of the operating business untouched. Skinny restructurings are close analogues to the kind of balance sheet restructurings that can be consummated in the UK, for example, through creditors' schemes of arrangement. ${ }^{49}$ Indeed, skinny restructuring is the main territory of pre-insolvency proceedings in practice.

\footnotetext{
${ }^{44} 11$ USC ss. 1141(d), 1142(a). We note in passing that the UK's creditors' scheme of arrangement, which has all the core characteristics of a pre-insolvency proceeding (formal court sanction, restructuring goal, no insolvency requirement, no effect on the legal status or authority of the debtor's management), does not have a cross-class cramdown feature. All classes must approve the scheme by the requisite statutory majorities before the court will sanction it. See Companies Act 2006 ss. 896(1), 899(1). Perhaps in an attempt to preserve the UK's comparative advantage in the European restructuring market post-Brexit, the UK government is proposing to introduce a new restructuring procedure, modelled on the scheme of arrangement, which will incorporate a cross-class cramdown feature and a flexible approach to absolute priority. See Department for Business, Energy \& Industrial Strategy, Insolvency and Corporate Governance-Government response (26 August 2018), pp 63-75. Debtors can currently cram down whole classes but only by twinning a scheme with a pre-packaged administration sale: see text to nn. 152-154 below.

${ }^{45}$ Paterson (2016), p 715.

${ }^{46}$ As well as various policy-based exceptions to the automatic stay in 11 USC s. 362(b), the bankruptcy court may grant relief from stay for cause or, insofar as the stay bars enforcement of rights to property, where the debtor does not have equity in the property and the property is not necessary to an effective reorganization: 11 USC s. 362(d).

47 As chronicled in Paterson (2016).

${ }^{48}$ Connolly (2004); Eidenmüller (2018b).

${ }^{49}$ Companies Act 2006, Pt 26. For a sample of the now extensive literature on schemes see Hargovan (2010); Olivares-Caminal et al. (2016); Payne (2013), (2014a, b), (2018).
} 
But as well as a range of restructuring outcomes, chapter 11 can also be used to accomplish court-approved sales that are functionally equivalent to various formal insolvency proceedings, for example, the UK administration sale. ${ }^{50}$ Here too, there are several possibilities. The court can approve a sale as part of a confirmed plan, ${ }^{51}$ or, prior to plan confirmation under section 363 of the Bankruptcy Code, in which case the sale is conjoined with a so-called liquidating plan, which becomes a vehicle for distributing the sale proceeds. ${ }^{52}$ More controversially, debtors-in-possession, invariably at the behest of their senior creditors, ${ }^{53}$ have pushed the envelope of the section 363 power to carry out quick going concern whole-of-firm sales without any kind of accompanying plan process. In these cases, after the sale, the debtor will either convert to a liquidation or simply get the chapter 11 case dismissed. ${ }^{54}$ Critics object that section 363 whole-of-firm sales, which courts review on a deferential business judgment standard, do an end run around chapter 11's plan protections for dissenting creditors and dissenting classes. ${ }^{55}$ Be that as it may, chapter 11 is at root a pre-insolvency proceeding-it has the four core characteristics we identified earlier ${ }^{56}$-although in practice, it is a hybrid restructuring and insolvency proceeding through which debtors and creditors can engineer a range of outcomes (skinny financial restructurings, wholesale reorganizations, asset sales followed by a distribution).

Chapter 11, through its debtor-in-possession (DIP) financing provisions, ${ }^{57}$ also provides a platform for the investment of new money in the firm to ensure continuity while a plan is negotiated. Subject to court approval, these provisions permit the firm to grant new lenders priming liens that confer priority on the new lender over existing lienholders. As such, the Bankruptcy Code establishes a backstop framework for resolving inter-creditor issues relating to the terms on which senior creditors will provide ongoing liquidity to the firm's operating business. In practice, the DIP financing provisions create governance leverage through which DIP lenders can control the course of the case. ${ }^{58}$ But for our purposes, they underscore the point that chapter 11 has always been much more than just a voting mechanism to accomplish a skinny restructuring before the debtor begins its descent down the demise curve. The Bankruptcy Code's elaborate provisions preventing ipso facto termination of

\footnotetext{
50 See UK Insolvency Act 1986, Part II and Schedule B1.

5111 USC s. 1123(a)(5)(D).

52 Cousins (2002).

53 Text to $n .18$ above.

54 A so-called structured dismissal: see Pernick and Dean (2010).

55 Such sales are commonly approved on the theory that the debtor firm is a 'melting ice cube' and the decision to sell quickly is therefore a reasonable commercial decision. Junior creditors left out of the money may well object that a restructuring, rather than a sale, would generate value that they could share in through the plan process. See further Jacoby and Janger (2014).

56 Text to nn. 23-27 above.

5711 USC s. 364. For background see Skeel (2004). International standard setters lay great store on post-commencement financing and barely disguise their admiration for the US DIP finance model. See IMF, Orderly \& Effective Insolvency Procedures (n. 9), sec 4, under the heading 'Post-commencement Financing'; UNCITRAL Legislative Guide (n. 9), pp 113-119.

58 Skeel (2004); Phelan and Tama (2011); American Bankruptcy Institute (2014), pp 73-83.
} 
contracts and empowering the debtor-in-possession to assume or reject its executory contracts and leases further illustrate chapter 11's breadth and hybridity. ${ }^{59}$

In setting a base line for minimum harmonization, the EU's emerging conception of pre-insolvency proceedings draws on chapter 11 's model. ${ }^{60}$ Thus, the focus on so-called pre-insolvency proceedings, in the form of processes akin to chapter 11, is becoming significantly widespread, although these are unlikely to emerge as a onesize-fits-all or a single uniform template for restructuring. The Directive's base line model possesses the core characteristics identified at the beginning of this section. It would require member states to ensure that, "where there is a likelihood of insolvency, debtors in financial difficulty have access to an effective preventive restructuring framework that enables them to restructure their debts or business' ${ }^{61}$ Thus, factual insolvency is not a pre-condition to access (third characteristic) ${ }^{62}$ and restructuring, rather than liquidation of assets and distribution of proceeds among creditors, is the outcome contemplated (second characteristic). The EU model is formal (first characteristic) in that it contains rules on plan contents, class formation, valuation, and voting, and requires member states to ensure that restructuring plans which affect the interests of dissenting parties, or which provide for new financing, can only become binding if they are confirmed by a judicial or administrative authority. ${ }^{63}$ The fourth characteristic_-debtor-in-possession-is also a default feature. ${ }^{64}$ However, the Directive does also contemplate partial DIP models in which officeholders may — and in some situations must—be appointed to oversee the case. ${ }^{65}$

5911 USC s. 365.

${ }^{60}$ Eidenmüller (2017), p 291 ('[The Commission proposal] looks like a Chapter 11 proceeding without strong court involvement from the beginning and without the tools needed for the court to guarantee a fair outcome of the process'); McCormack (2017), p 537 ('There are undoubtedly strong similarities between the European restructuring proposals and Ch.11').

${ }^{61}$ Directive (n. 6), Art. 4(1). For background see Commission Proposal (n. 6), p 37; Council Position (n. 6), p 54.

${ }^{62}$ Directive (n. 6), recital (24)) ('A restructuring framework should be available before a debtor becomes insolvent under national law, namely before the debtor fulfils the conditions under national law for entering collective insolvency proceedings [...]'). The Directive contemplates the possibility of access limitations in the form of a viability test while, at the same time, permitting member states, should they wish, to extend the scope of preventive restructuring frameworks to 'situations in which debtors face non-financial difficulties, provided that such difficulties give rise to a real and serious threat to a debtor's actual or future ability to pay its debts as they fall due'. See Directive, Art. 4(3), recital (28). This reflects a compromise between member states concerned that non-viable debtors would use preventive proceedings to delay entry into full insolvency proceedings and thus risk diminishing the value of the estate and member states who favour easy access to preventive proceedings. For background see Commission Proposal (n. 6), p 28; Council Position (n. 6), p 3.

${ }_{63}^{63}$ Directive (n. 6), Arts. 8-10, 14-15.

${ }^{64}$ Ibid., Art. 5.

${ }^{65}$ Ibid., Art. 5(2), (3). Member states have the option to provide for the appointment of a practitioner on a case by case basis except where national law insists on a mandatory appointment. This reflects the range of accumulated experience that European jurisdictions have with partial DIP or hybrid models. For example, an insolvency practitioner must be appointed to act as nominee and supervisor of a UK company voluntary arrangement, and in a French sauvegarde proceeding the court usually appoints an administrator to assist with or supervise the debtor's negotiations with creditors. See Weil, Gotschal and Manges (2012). On the French law resonances in the Commission's original proposal for the Directive, see further McCormack (2017), p 544. As a minimum, the Directive requires member states to provide 
The proceedings contemplated by the Directive bear some resemblance to chapter 11 but are far from identical to it. For example, chapter 11's automatic stay and DIP financing provisions are significantly watered down and, some of the proposed standards, such as the 'likelihood of insolvency' access standard, retain, as one would expect, a distinctly European character that reflects compromises among the EU institutions and the member states. ${ }^{66}$ The directive seeks to minimize court involvement in the interests of efficiency and cost-effectiveness ${ }^{67}$ and arguably, therefore, provides the basis for a suite of cheaper European alternatives to the American system in which the institutional role of the court and of creditors' committees comes with a considerable price tag. Formal court sanction is therefore a feature of the EU model, but the role of the court is expected to be more 'light touch'.

In summary, at its core a pre-insolvency proceeding is a form of voting mechanism by which a debtor can seek to avoid insolvency by imposing a debt (usually balance sheet) restructuring on holdout creditors. Yet, while chapter 11-like processes can be deployed as pre-insolvency proceedings in the manner just described, they are really hybrid restructuring and insolvency proceedings that debtors (whether already insolvent or in anticipation of insolvency) can use to reallocate or realize firm value in various ways, which, for simplicity, we have characterized as skinny restructurings, wholesale reorganizations and sales. Insofar as it approximates to a 'chapter 11-lite' model, the Directive would create the legal foundation for the continued emergence of a range of European restructuring proceedings with considerable variance in design and detail ${ }^{68}$ and potential also for hybridity. This point is important because hybridity presents considerable challenges of characterization from a private international law perspective.

\section{The Treatment of Pre-insolvency Proceedings in Current Cross-Border Insolvency Law}

\subsection{Legal Framework}

The current global framework for coordinating cross-border insolvencies is still patchy in situations where it relies on a transnational web of domestic private international laws. But considerable progress has been made towards harmonization of the private international law of insolvency mainly through two instruments: the

\footnotetext{
Footnote 65 (continued)

for appointment of a practitioner in three situations enumerated in Art. 5(3), including cases involving cross-class cramdown.

66 Concern for managerial abuse - a key variable in explaining Europe's historic antipathy towards debtor-in-possession regimes-has not entirely gone away: see n. 62 above. Additionally, concern that directors will fail to act quickly enough is present too: Directive (n. 6), Art. 19.

67 Directive (n. 6), recital (29), Art. 4(6).

68 For example, as to the extent of court oversight. On the court's role in restructuring proceedings see generally Payne (2018).
} 
EU Insolvency Regulation (recast) ('EIR') ${ }^{69}$ and the UNCITRAL Model Law on Cross-Border Insolvency Law ('Model Law'). ${ }^{70}$ Domestic versions of the Model Law have been enacted by 46 jurisdictions to date, ${ }^{71}$ including key jurisdictions with large financial markets such as the United States, ${ }^{72}$ the United Kingdom, ${ }^{73}$ and Singapore. ${ }^{74}$ These two instruments seek to avoid a costly multiplicity of proceedings and promote centralized, coordinated, and therefore value-maximizing, resolution of cross-border cases.

The EIR harmonizes rules on jurisdiction, applicable law, recognition and international effect of insolvency proceedings and insolvency-related judgments throughout the EU. The Model Law creates a framework for international recognition and relief of eligible proceedings. ${ }^{75}$ Its aim is to promote harmonization through unilateral country adoptions of the transnational system as well as shared interaction and practice among enacting states over time. $^{76}$

The norm animating both instruments is modified universalism. Modified universalism's core tenet is a centralizing principle which gives primacy to a 'main' proceeding conducted in the jurisdiction where the debtor has its 'home country' and places courts in other jurisdictions in a supporting role. Under modified universalism, the 'main' proceedings' court is the hub of the wheel and other courts assist the 'main' proceeding so as to centralize the administration of the debtor's estate as far as possible. ${ }^{77}$ Modified universalism holds that courts should strive to achieve 'unity' (a single forum) and 'universality' (a single applicable insolvency

\footnotetext{
69 Regulation (EU) 2015/848 on insolvency proceedings (recast) [2015] OJ L141/19, which applies to insolvency proceedings opened after 26 June 2017. The recast replaces the original Insolvency Regulation, Council Regulation (EC) No. 1346/2000 [2000] OJ L160/1.

70 UNCITRAL Model Law on Cross-Border Insolvency (1997) ('Model Law') with Guide to Enactment (2013), UN Sales No. E 14 V2 (2014) ('Guide to Enactment'). The Model Law framework is also being expanded as new model laws have been developed to close certain gaps in the system. See the new Model Law on the Recognition and Enforcement of Insolvency-Related Judgments (UNCITRAL Model Law on Recognition and Enforcement of Insolvency-Related Judgments with Guide to Enactment (2019), https://uncitral.un.org/sites/uncitral.un.org/files/media-documents/uncitral/en/ml_recognition_ gte_e.pdf and the Model Law on Enterprise Group Insolvency (2019), https://uncitral.un.org/sites/uncit ral.un.org/files/media-documents/uncitral/en/mlegi_-_advance_pre-published_version_-_e.pdf, Annex, Draft model law on enterprise group insolvency.

71 For the current list of jurisdictions with Model Law enactments see https://uncitral.un.org/en/texts/ insolvency/modellaw/cross-border_insolvency/status.

7211 USC ss. 1501-1532.

73 Cross-Border Insolvency Regulations 2006 SI 2006/1030 (Great Britain); Cross-Border Insolvency Regulations (Northern Ireland) 2007 SI 2007/115 (NI) pursuant to Northern Ireland's devolution arrangements.

74 Companies (Amendment) Act 2017, s. 50, amending the Companies Act 1967 (revised edition 2006) by inserting a Singaporean Model Law enactment as the tenth schedule.

75 Walters (2019).

76 Dawson (2018), p 678 ('Nations that adopt the Model Law commit themselves to coordinate with foreign bankruptcy proceedings whenever a foreign bankruptcy trustee [...] opens a proceeding under the Model Law. Such a model law effort has network effects, with greater value the more widely it is adopted').

77 Ibid., p 684 ('Modified universalism [...] creates a hub-and-spoke model of cross-border insolvency with a "full” bankruptcy proceeding in one jurisdiction and ancillary proceedings around the perimeter').
} 
law) when it is the most efficient approach, and take a global perspective, with the aim of creating market symmetry between the cross-border insolvency system and transnational commercial reality. ${ }^{78}$ But modified universalism acknowledges that a fully universalist system - a single, unitary, worldwide proceeding administered in all cases from the debtor's 'home' jurisdiction, under 'home' law-does not always fit the enterprise structure and its geographical spread, and does not take account of differences in jurisdictions' capacity and level of adherence to minimum standards regarding insolvency. ${ }^{79}$ The EU and global instruments (by which we mean the various instruments promulgated by UNCITRAL, primarily the Model Law) ${ }^{80}$ that generally accord with modified universalism reflect a realistic approach to the administration of cross-border insolvency. At the core of the EIR and the Model Law is the notion of a debtor's COMI (centre of main interests) where the main proceedings should be opened (under the EIR) or that should be recognized as the main proceedings (under the Model Law). Additional 'secondary' proceedings may be opened, however, under the EU system or 'non-main' proceedings may be recognized under the Model Law. The instruments also provide certain safeguards that reflect the persistence of national legal orderings, in particular a standard public policy ground for denial of recognition and/or relief. ${ }^{81}$

In practice, the cross-border insolvency instruments streamline the basis on which the effects of a proceeding in the debtor's 'home' jurisdiction can be extended beyond that jurisdiction. This way, assets in other jurisdictions can be protected from individual enforcement and marshalled, and restructuring plans approved by the 'home' court can be globally enforced. As well as creating a framework of private international law rules for insolvency, the instruments also promote a wider culture of international cooperation by establishing extensive duties of cooperation and communication between courts and between practitioners. ${ }^{82}$

\subsection{Proceedings Eligible for Assistance and Cooperation Under Cross-Border Insolvency Law: Definitions and Predicates}

The threshold question is: what proceedings fall within the scope of the current cross-border insolvency instruments? In other words, how do these instruments

\footnotetext{
78 Leading universalists advocate for courts to interpret the Model Law as a 'systems' text that establishes an institutional and procedural framework for accomplishing a centralizing goal. In substance, this is an exhortation to judges to default to a universalist interpretation to fill gaps where they are not obviously constrained from so doing. See Westbrook (2015, 2018); and further discussion by Dawson (2018) and Walters (2019).

79 Walters (2019); Mevorach (2018a), ch. 1 (outlining the contours of modified universalism and recapping cross-border insolvency's 'universalism' versus 'territorialism' debate).

${ }^{80}$ See also the new model laws on the enforcement of insolvency-related judgments and on enterprise groups insolvency (n. 70 above). These models aim to complement the Model Law and to close gaps to facilitate recognition and relief of insolvency-related judgments and to promote group solutions, including when the COMI of group members is located in different jurisdictions. See further Mevorach (2018a), pp 221-236.

81 EIR, Art. 33; Model Law, Art. 6.

82 EIR, Arts. 42-43; Model Law, Arts. 25-27.
} 
separate the proverbial sheep (eligible proceedings) from the proverbial goats (ineligible proceedings)? We consider the position under the Model Law and the EIR in turn.

\subsubsection{The Model Law}

The Model Law applies-and therefore its benefits become available-predominantly where a foreign court or foreign representative seeks assistance in the enacting state in connection with a 'foreign proceeding' ${ }^{83}$ A proceeding must be a 'foreign proceeding' to qualify for recognition. ${ }^{84}$ Article 2(b) defines 'foreign proceeding' as:

[A] collective judicial or administrative proceeding in a foreign State, including an interim proceeding, pursuant to a law relating to insolvency in which proceeding the assets and affairs of the debtor are subject to control or supervision by a foreign court, for the purpose of reorganization or liquidation.

The definition is intended to be expansive ${ }^{85}$ and to encompass proceedings involving debtors that are in severe financial distress or insolvent, including proceedings accessible to debtors 'that are or will be generally unable to pay their debts as they mature'. ${ }^{86}$ In principle, then, the Model Law can accommodate proceedings across the spectrum, including preventive and hybrid proceedings, and apply to them the sui generis private international law system of insolvency based on modified universalism.

The commentary in the Model Law's Guide to Enactment on each of the predicates-'collective', 'law relating to insolvency', 'debtor's assets and affairs subject to the control or supervision of a court', 'liquidation or reorganization'

\footnotetext{
${ }^{83}$ Model Law, Art. 1(a).

${ }^{84}$ Ibid., Arts. 15(1), 17(1)(a). Ultimately, only foreign main proceedings or foreign non-main proceedings qualify for recognition. See Arts. 2(b), (c), 17(2). Our article is concerned solely with the threshold question.

${ }^{85}$ Guide to Enactment, paras. 65 ('The definitions of proceedings [...] avoid the use of expressions that may have different technical meaning in different legal systems and instead describe their purpose or function. This technique is used to avoid inadvertently narrowing the range of possible foreign proceedings that might obtain recognition and to avoid unnecessary conflict with terminology used in the laws of the enacting State [...]'), 71 ('Within the parameters of the definition of a foreign proceeding, a variety of collective proceedings would be eligible for recognition, be they compulsory or voluntary, corporate or individual, winding-up or reorganization. The definition would also include those proceedings in which the debtor retains some measure of control over its assets, albeit under court supervision [...]'), 72 ('The Model Law recognizes that, for certain purposes, insolvency proceedings may be commenced under specific circumstances defined by law that do not necessarily mean the debtor is in fact insolvent $\left.[\ldots]^{\prime}\right)$.

${ }^{86}$ Ibid., para. 49 (emphasis added). See further paras. 65 ("[...] the expression "insolvency proceedings" may have a technical meaning in some legal systems, but is intended in subparagraph (a) to refer broadly to proceedings involving debtors that are in severe financial distress or insolvent.'), 67 ('[ ...] the focus of the Model Law is upon severely financially distressed and insolvent debtors and the laws that prevent or address the financial distress of those debtors $[\ldots]$ ').
} 
purpose-supports a broad, inclusive reading. ${ }^{87}$ The requirement for 'collectivity' rules out de facto collection proceedings that enable individual creditors or groups of creditors to enforce their claims, such as a receivership instigated by a secured creditor. ${ }^{88}$ But proceedings are not necessarily ruled out because they leave a class of creditors' rights unaffected:

A proceeding should not be considered to fail the test of collectivity purely because a class of creditors' rights is unaffected by it. An example would be insolvency proceedings that exclude encumbered assets from the insolvency estate, leaving those assets unaffected by the commencement of the proceedings and allowing secured creditors to pursue their rights outside of the insolvency law $[\ldots] .{ }^{89}$

In practice, 'collectivity' apparently would also not rule out skinny restructurings that address balance sheet liabilities while leaving the claims of operating creditors untouched on the argument that the restructuring affects, and affords due process rights, to all creditors included within its scope. ${ }^{90}$ A proceeding is not ruled out merely because it is conducted under a law that is not designated as an insolvency law or does not contain rules relating exclusively to insolvency. ${ }^{91}$ Function carries more weight than form. Thus, for example, a company law proceeding, like a UK scheme of arrangement, which can be used for solvent and distressed/insolvent restructurings may still be a 'proceeding [...] pursuant to a law relating to insolvency' under Article 2(a) of the Model Law. ${ }^{92}$ While the debtor's assets and affairs

${ }^{87}$ Ibid., paras. 65-80.
${ }^{88}$ Ibid., para. 69. In re Betcorp Ltd 400 BR 266 (Bkrtcy D Nev 2009), p 281; In re Gold \& Honey, Ltd
410 BR 357 (Bkrtcy EDNY 2009), pp 369-371. See also In re Ashapura Minechem Ltd 480 BR 129
(Bkrtcy SDNY 2012).
${ }^{89}$ Guide to Enactment, para. 70. This is, for example, the case in a winding-up under the Insolvency Act 1986, which is regarded in the law of England and Wales as a collective execution for unsecured creditors. See Buchler v. Talbot [2004] UKHL 9, [2004] 2 AC 298, [28]-[30] (Lord Hoffmann), [51]-[52] (Lord Millett). See also In re ABC Learning Centres Ltd 445 BR 318 (Bkrtcy D Del 2010) (voluntary winding-up co-existing with receivership 'collective' as liquidators working to realize unencumbered assets, including avoidance and insolvent trading claims, for the benefit of unsecured creditors).

90 See, in relation to UK schemes of arrangement, Seife and Vazquez (2008), p 576. The Guide to Enactment, para. 78 rules out workouts (financial adjustment on a purely contractual basis) on the grounds that they 'would generally not satisfy the requirement for collectivity nor for control or supervision by the court'. We would rule them out because they are not 'proceedings': see Betcorp (n. 88), pp 277-280, especially at p 278 ('In the context of corporate insolvencies, the hallmark of a "proceeding" is a statutory framework that constrains a company's actions and that regulates the final distribution of a company's assets'). Inevitably, there are questions at the margins, e.g. would a proceeding affecting a single class of note holders be too skinny to qualify?

91 In re Agrokor dd [2017] EWHC 2791 (Ch), [2018] Bus LR 64, [55]. Agrokor and Betcorp support the proposition that a proceeding is pursuant to a law relating to insolvency if insolvency is one of the grounds on which the proceeding can be commenced. See Agrokor, [58]-[63].

92 We would contend that 'law relating to insolvency' is intended to include preventive proceedings designed to help a debtor avoid insolvency. Agrokor (n. 91) provides some support for this proposition at [64]-[73]. The US and Singapore enactments of the Model Law put the point beyond doubt in their respective jurisdictions by expanding the predicate to read 'a law relating to insolvency or adjustment of debt'. See 11 USC 101(23); Singapore Companies Act s. 354B, Sch 10, Art. 2(h); In re Avanti Communications Group plc 582 BR 603 (Bkrtcy SDNY 2018), p 614. 
must be subject to the control or supervision of a court, ${ }^{93}$ control or supervision may be potential rather than actual and need not be exercised directly. ${ }^{94}$ A proceeding administered by an insolvency practitioner would still qualify as long as the insolvency practitioner is subject to court supervision. ${ }^{95}$ DIP and partial DIP proceedings, in which the debtor retains control over its assets subject to court oversight, are intended to qualify. ${ }^{96}$ The 'liquidation or reorganization' predicate is also prima facie broad enough to include proceedings that lead to one or more of a range of outcomes-break-up sales, going concern sales, wholesale restructurings, and skinny restructurings involving balance-sheet 'reorganization'97 — and therefore brings multi-purpose hybrid proceedings inside the tent.

\subsubsection{The EIR}

In its original version, the EIR, and the lapsed draft EU Convention on which it was based, ${ }^{98}$ applied to "collective insolvency proceedings which entail the partial or total divestment of a debtor and the appointment of a liquidator' ${ }^{99}$ This narrow definition, which required proceedings to be based on the debtor's insolvency and not on other grounds, ${ }^{100}$ reflected the liquidation and management displacement biases of European insolvency systems that were prevalent 30 years ago. The updated scope of the recast Regulation is broader and captures the institutionalization of rescue within European insolvency systems in the intervening years, while also foreshadowing the EU's preventive restructuring initiative. ${ }^{101}$ Article 1(1) of the EIR, insofar as relevant to our present discussion, now reads as follows:

This Regulation shall apply to public collective proceedings, including interim proceedings, which are based on laws relating to insolvency and in which, for the purpose of rescue, adjustment of debt, reorganization or liquidation:

\footnotetext{
93 Guide to Enactment, para. 76, Gold \& Honey (n. 88), p 371.

94 Guide to Enactment, para. 74 ('The Model Law specifies neither the level of control or supervision required to satisfy this aspect of the definition nor the time at which that control or supervision should arise. Although it is intended that the control or supervision required under subparagraph (a) should be formal in nature, it may be potential rather than actual [...]').

95 Ibid. ('[...] Control or supervision may be exercised not only directly by the court but also by an insolvency representative where, for example, the insolvency representative is subject to control or supervision by the court [...]').

96 Ibid. (" $[\ldots]$ a proceeding in which the debtor retains some measure of control over its assets, albeit under court supervision, such as a debtor-in-possession would satisfy this requirement [...]').

97 Ibid., para. 77 (which rules out proceedings that simply preserve assets but, by inference, and read in the context of the commentary as a whole is intended to be inclusive).

98 See Fletcher (2005), pp 341-346.

99 Council Regulation (EC) No. 1346/2000 on insolvency proceedings [2000] OJ L160/1 Art. 1(1); M. Virgos and E. Schmit, Report on the Convention on Insolvency Proceedings, EU Council 6500/1/96, REV 1, DRS 8 (CFC) (1996) ('Virgos-Schmit'), para. 48.

100 Virgos-Schmit (n. 99), para. 49.

101 Hess et al. (2014), pp 24-67; Omar (2014); Eidenmüller and van Zwieten (2015), p 642 ('The European Commission's "preventative restructuring framework" for Member States is intended to operate in tandem with, and be complemented by, the jurisdictional and private international law framework set up by the EIR').
} 
(a) a debtor is totally or partially divested of its assets and an insolvency practitioner is appointed;

(b) the assets and affairs of a debtor are subject to control or supervision by a court; or

(c) a temporary stay of individual enforcement proceedings is granted by a court or by operation of law, in order to allow for negotiations between the debtor and its creditors, provided that the proceedings in which the stay is granted provide for suitable measures to protect the general body of creditors, and, where no agreement is reached, are preliminary to one of the proceedings referred to in point (a) or (b).

Where the proceedings referred to in this paragraph may be commenced in situations where there is only a likelihood of insolvency, their purpose shall be to avoid the debtor's insolvency or the cessation of the debtor's business activities.

Under the influence of the Model Law definition of 'foreign proceeding', aspects of which are apparent in the opening language of Article 1(1), the recast Regulation's scope is wide enough to encompass pre-insolvency, debtor-in-possession style proceedings as well as more traditional insolvency or rescue proceedings for which insolvency is a pre-condition. ${ }^{102}$ Moreover, skinny restructurings affecting only some creditors are explicitly brought within the Regulation's scope. ${ }^{103}$ On the flipside, as is also the case with the Model Law, out-of-court workouts are 'out': they are not 'public'104 and do not involve court supervision or control.

But despite cross-fertilization, the EIR and Model Law differ in important respects. First, while Article 1(1) sets parameters, it is not dispositive. In the interests of legal certainty, the proceedings within the scope of the EIR are listed for each member state in Annex A, a practice that originated with the draft Bankruptcy Convention. ${ }^{105}$ The Court of Justice of the European Union has ruled that Annex A determines

\footnotetext{
${ }^{102}$ EIR, recital (10) ('The scope of this Regulation should extend to proceedings which promote the rescue of economically viable but distressed businesses $[\ldots]$. It should $[\ldots]$ extend to proceedings which provide for restructuring of a debtor at a stage where there is only a likelihood of insolvency and to proceedings which leave the debtor fully or partially in control of its assets and affairs'). The Commission intends its proposed preventive insolvency framework and the recast Regulation to complement one another. See Commission Proposal (n. 6), p 9; Directive (n. 6), recitals (12)-(13); cf. Eidenmüller (2018a), p 59.

${ }^{103}$ EIR, recital (14) ('The collective proceedings which are covered by this Regulation should include all or a significant part of the creditors to whom a debtor owes all or a substantial proportion of the debtor's outstanding debts provided that the claims of those creditors who are not involved in such proceedings remain unaffected. Proceedings which involve only the financial creditors of a debtor should also be covered'); Art. 2(1) (defining 'collective proceedings' along similar lines).

104 Ibid., recitals (12)-(13).

${ }^{105}$ Ibid., Art. 1(1) (last line), Art. 2(4); Virgos-Schmit (n. 99), para. 9 ('Two Annexes to the Convention determine the national proceedings covered by the Convention. These Annexes form an integral part of the Convention).
} 
exhaustively whether or not a national proceeding qualifies: if it's on the list, it's 'in' even where there are doubts about whether it meets the Article 1(1) criteria ${ }^{106}$; if it's not on the list, it's 'out'. ${ }^{107}$ To update the Annex, countries must notify the Commission of changes to domestic law and request the amendment of Annex A so that it accurately reflects national notifications. On receiving such a request, the Commission reviews it and proposes a regulation to replace Annex A with an updated list. Thus, the Regulation has the character of an 'opt in' instrument in terms of the proceedings covered. If member states choose not to notify a particular proceeding, it will not be in Annex A and will therefore be outside the Regulation's scope.

Second, the Regulation attaches a formalistic meaning to 'law relating to insolvency'. Recital (16) expressly rules out proceedings 'based on general company law not designed exclusively for insolvency situations'. Thus, a multi-purpose Companies Act proceeding that can function as a pre-insolvency or insolvency proceeding, albeit non-exclusively, is 'out'. This goes some way to explaining why UK schemes of arrangement are outside the scope of the EIR ${ }^{108}$ despite routinely being recognized as eligible foreign proceedings by US courts under chapter 15 of the Bankruptcy Code, the US enactment of the Model Law. ${ }^{109}$

\section{Pre-insolvency Proceedings in Private International Law: Contract or Insolvency?}

We saw in Sect. 3 that the trajectory of cross-border insolvency law as reflected in the key international instruments has generally kept track with the evolution of insolvency and restructuring law. If we leave aside the difference between the Model Law and the EIR concerning 'law relating to insolvency', the only resolution tools decisively beyond the pale are out-of-court workouts and creditor-initiated individual collection mechanisms. We can argue about whether 'light touch' preventive restructuring proceedings having the characteristics outlined in Sect. 2 are sufficiently public, ${ }^{110}$ sufficiently collective (where they affect only a narrow tranche of creditors), and sufficiently court supervised, but we suggest that the prevailing inclination of the law is towards inclusivity.

\footnotetext{
106 Case C-116/11 Bank Handlowy w Warszawie SA v. Christianapol sp z oo, EU:C:2012:739.

107 Case C-461/11 Ulf Kazimierz Radziejewski v. Kronofogdemyndigheten i Stockholm, EU:C:2012:704; EIR, recital (9). The point is further illustrated by Agrokor (n. 91). In Agrokor, the English High court recognized a Croatian extraordinary administration proceeding under an applicable Model Law enactment. The court could not recognize the Croatian proceeding under the Regulation because it was not listed in Annex A.

108 See further Block-Lieb (2018), p 29. It is also worth noting that a number of 'scheme-like' proceedings that form part of the domestic insolvency and restructuring law of other EU member states are included in the Annex, e.g. the Spanish homologation proceeding and the Dutch suspension of payment proceeding (which can lead to a composition).

109 Avanti Communications (n. 92), p 613. It can be argued, regardless of the Annex, that the assets and affairs of a scheme debtor are not subject to the control or supervision of a court within EIR, Art. 1(b): see Block-Lieb (2018), p 30. However, as the court is directly involved in convening meetings, signing off on class formation, and sanctioning the scheme, US courts applying the same language in 11 USC 101(23) have assumed, to date, that scheme debtors are, at very least, subject to court supervision.

110 Eidenmüller (2018a), pp 59-60.
} 
This trend towards inclusivity raises normative questions. Is cross-border insolvency law over-inclusive? Should the tools of cross-border insolvency law be available to universalize the effects of a domestic pre-insolvency proceeding on foot in the jurisdiction of the debtor's COMI? Should we redraw the boundaries and make cross-border insolvency law less inclusive? Is it necessary, or at the very least desirable, for pre-insolvency proceedings to receive international recognition, assistance and cooperation on much the same terms as insolvency proceedings?

\subsection{The'Full Collectivity' Theory}

It can be argued that the touchstone for universal applicability under cross-border insolvency law should be whether a proceeding is 'fully' collective. On one influential view, a proceeding is only fully collective where it deals with all creditors to resolve a common pool problem by restricting individual rights of enforcement either procedurally, by means of a stay, or substantively by modifying creditor entitlements. ${ }^{111}$ It follows from this view that insolvency law should only be permitted to override the legitimate expectations of creditors, including expectations as regards the anticipated forum for, and law applicable to, the resolution of their claims, where the proceeding is fully collective. ${ }^{112}$ This full collectivity theory is primarily concerned to protect the private autonomy of contract creditors, expressed through forum selection and governing law clauses, from unjustified encroachment by the COMI jurisdiction's insolvency law. ${ }^{113}$ In short, under the full collectivity theory, unless the proceeding purports to deal procedurally or substantively with a situation of general default- that is, one that in some way addresses the claims of all creditors long term (finance) or short/medium term (operating) — they should be excluded. Thus, the US chapter 11 proceeding would be included because it imposes a wide stay and allows 'forced modifications of creditors' entitlements', ${ }^{114}$ but the UK scheme of arrangement or the French procédure de financière sauvegarde accélérée would be excluded, as these proceedings can be characterized as 'not fully collective', because their goal is restricted to accomplishing 'an early financial

\footnotetext{
111 Ibid., pp 66-68.

112 Ibid., pp 67-68, 70, 71. Eidenmüller particularly has in mind the automatic universalizing effects of the EIR. Strictly, as again he is careful to acknowledge (at p 55), the effects of recognition are weaker under the Model Law. This is because (i) recognition in the Model Law does not automatically flow from the 'home' court's claim to jurisdiction and (ii) the Model Law has no equivalent to the EIR's applicable law provisions. Even so, jurisdictions that incline towards a strong theory of modified universalism do extend the overriding effects of the foreign insolvency law as a practical matter under the Model Law. The practice under chapter 15 of US courts granting permanent injunctions in aid of foreign reorganizations de facto extending foreign discharges to US territory is illustrative. See e.g. Avanti Communications (n. 92); In re Energy Coal SPA (2018) 582 BR 619.

113 Eidenmüller (2018a), p 70 ('Nobody has to accept that [their] claim shall be reduced in a forum different from that which was contractually agreed or would be available under the non-insolvency rules of the applicable international civil procedure regime. Further, nobody has to accept a claim modification based on laws and regulations different from the law governing his or her claim'). The view expressed seems to extend to the treatment non-contract claimants might expect under ordinary private international law.

114 Ibid., pp 68-69.
} 
restructuring of portions of creditors' claims'. ${ }^{115}$ One important implication of full collectivity is that pre-insolvency proceedings designed to promote skinny financial restructuring should be treated as a species of de facto private resolution and the logic of contractual workouts should still prevail.

\subsection{The 'Separate Domains/Separate Normative Foundations' Theory}

Another way to address the trend towards over inclusiveness is to sever more sharply insolvency proceedings from restructuring proceedings and treat insolvency law and restructuring law as separate domains with separate functions and distinctive normative foundations. ${ }^{116}$ According to this 'separate domains' theory, the domain of insolvency law is asset realization proceedings that respond to a common pool problem whereas the domain of restructuring law is court-assisted agreements among stakeholders about future entitlements to future revenue streams. The former protects assets from a destructive enforcement race and provides instead for collective enforcement of claims against an insufficient pool of assets and distribution on liquidation principles. The latter involves a new bargain between the debtor and creditors about future revenues. ${ }^{117}$ Under this theory, a legal framework that supports structured bargaining over future value differs from a collective liquidation and distribution of assets because it responds to an anti-commons problem rather than a common pool problem. ${ }^{118}$ Accordingly, restructuring law ought properly to be based on contract and company law principles - with the law supplying deadlock resolution procedures to overcome the problem of holdout vetoes standing in the way of the new bargain - rather than on the distributive norms of liquidation law.

The separate domains theory does more than merely address the policy dilemma of cross-border characterization. It aims more widely to decouple restructuring law from liquidation principles (including the absolute priority rule) and ground it on the expectations of stakeholders outside of insolvency. ${ }^{119}$ We have much sympathy with the idea that the methodology for determining whether entitlements to future value in a restructuring have been allocated fairly and equitably should not be wedded to

\footnotetext{
115 Ibid., p 69. Eidenmüller also excludes UK winding-up proceedings because they do not stay enforcement by secured creditors. On the same logic, he would presumably exclude company voluntary arrangements because they neither stay nor are capable of modifying the entitlements of secured and preferential creditors without their consent: see Insolvency Act 1986, s. 4(3), (4).

116 See Madaus (2018).

117 Ibid., section 3.2.

118 A commons or common pool problem arises where uncoordinated individual exploitation of a freely accessible but limited resource will destroy the resource. An anti-commons problem arises where ownership rights are fragmented, and value is lost because individual owners can veto coordinated use of property with the result that it is under-utilized. See Madaus (2018), section 5.1. The seminal reference on anti-commons problems is Heller (1998). See also Heller (2008).

119 Madaus (2018), section 3.2. As such, Madaus seeks to shed the influence of US law and constitutionalize restructuring law on European legal foundations, which, in contrast to US law, permit impairment of contracts at individual state level: ibid., section 4.2.5.
} 
counterfactual liquidation outcomes. ${ }^{120}$ However, we are concerned that the separate domains theory would carve out restructuring proceedings, including skinny restructurings and restructuring aspects of hybrid proceedings, ${ }^{121}$ from the scope of crossborder insolvency law, leaving the cross-border issues to be resolved by ordinary private international law.

\subsection{In Defence of the Emergent Status Quo}

We worry about under-inclusiveness for several reasons. First, insolvency and restructuring law may be best seen as a unified body of law-and a unified jurisdiction-which responds to various kinds of collective action problem with the goal of preserving and maximizing value. Against this backdrop, any move to exclude preinsolvency proceedings from cross-border insolvency law runs into two problems: (1) restructuring cases higher up the demise curve will arise where debtors will need cross-border assistance and cooperation under existing cross-border insolvency instruments to accomplish desirable outcomes; and (2) the legal response to situations of distress that have multinational elements will become fragmented according to the point on the demise curve where the intervention takes place or depending on the manner of the intervention.

The main case against inclusiveness in cross-border cases is that insolvency law and its related jurisdiction has no business overriding the private autonomy of contract debtors in restructuring contexts involving 'contractualized' or semicontractual debt resolution. The objection is that the universal extension (and thus rigid over-reaching) of the COMI court's law and jurisdiction harms the legitimate expectations of creditors who contracted for some other governing law and preselected some other forum for resolution of their (debtor-creditor and inter-creditor) disputes. $^{122}$

However, in skinny restructurings, the creditors are invariably sophisticated multinational parties whose expectations will be shaped as much by prevailing trends in the restructuring market as by contract. It will hardly come as any surprise to

\footnotetext{
120 This may be done within a unified body of insolvency and restructuring law. See, for example, Department for Business, Energy \& Industrial Strategy, Insolvency and Corporate Governance (n. 44), pp 71-74 (UK government proposals for a new restructuring proceeding that would incorporate a 'best alternative' valuation rather than a liquidation valuation methodology and a flexible approach to absolute priority). The Directive steers member states towards adoption of a relative priority rule under which a cross-class cramdown could be confirmed where 'dissenting voting classes of affected creditors are treated at least as favourably as any other class of the same rank and more favourably than any junior class'. See Council Position (n. 6), p 6; Directive (n. 6), Art. 11(1)(c). But it permits member states to derogate from relative priority in favour of an absolute priority rule should they so wish. See Directive (n. 6), Art. 11(2).

121 Cf. Madaus (2018), Sect. 4.3.

122 From there the objection usually takes an economic turn, i.e. that the overriding of creditor expectations will affect the cost of credit ex ante which is even more crucial as it does not only affect those firms that have entered into insolvency proceedings but also firms and parties contracting with them that might potentially become insolvent. See Hart (1995), ch. 7. However, while assertions about negative effects on cost of credit are commonplace, we rarely see them backed up by reliable empirical evidence.
} 
such creditors that a debtor in a state of pre-insolvency distress may seek to restructure in a venue conducive to achieving a favourable restructuring outcome in as efficient a manner as possible. To be sure, there may be concerns about abusive forum shopping-including the ability of debtors to migrate their COMIs and so displace privately agreed governing law and dispute resolution mechanisms with an 'alien' COMI state restructuring regime-but the reality is that it is difficult to achieve a successful restructuring without a sizeable majority of the debtor's finance creditors on board. Those creditor majorities that are already onside with the restructuring effort invariably select (or influence the selection of) the restructuring venue ${ }^{123}$ and expect to do so.

In truth, then, the concern about the COMI court/law defeating creditor expectations distils down to a concern about appropriate counter-majoritarian minority protections for potential holdouts that dislike the majority's chosen mechanism for breaking any deadlock and the terms of the proposed deal. Minority protection, of course, is important. However, if expectations-as we would contend-are shaped organically by practice in debt markets, it is difficult to understand why the contractual expectations of the minority, represented by venue and governing law clauses in the finance documents, should be automatically dispositive if the majority wishes to modify the contract in a restructuring regime of its choice when distress arises. ${ }^{124}$ Further, skinny restructurings that require formal mechanisms to break deadlocks or bind in unknown creditors do have externalities that affect not only the finance creditors. A successful restructuring will nip a crisis in the bud and help to ensure that established relationships between the debtor and its operating creditors continue to flourish.

Second, cross-border insolvency law's dominant norm, modified universalism, can provide scaffolding for ensuring creditors are treated fairly in foreign jurisdictions, including through the safeguards it provides such as the public policy standard or the notion of 'adequate protection'. ${ }^{125}$ We take this discussion up further in Sect. 5, but for now we note as well that modified universalism is a flexible norm that can be developed to accommodate the peculiarities of pre-insolvency proceedings and thus address concerns about over-inclusivity, within the ambit of cross-border insolvency law.

Third, attempts to sever restructuring law (which responds to likelihood of insolvency) and insolvency law (which responds to factual insolvency) might do more harm than good. If we conceive of problems of financial distress as being on a curve-the demise curve-or, without much variation, on a downward spiral, and we accept the proposition that early intervention higher up the curve may often be more desirable than later intervention lower down the curve, insolvency

\footnotetext{
123 Walters (2017), text to fn. 38. Furthermore, creditors use other contractual devices such as COMI representations and covenants to try to predetermine the venue for insolvency and restructuring proceedings. See e.g. Re Videology Limited [2018] EWHC 2186 (Ch), [2019] BCC 195, [64]-[69].

124 Especially where majority expectations may also be shaped by contractual provisions such as COMI representations and covenants that steer towards a COMI that is different from the governing law of the contract and minority expectations can be accommodated, for example, by Model Law concepts such as adequate protection.

125 EIR, Arts. 33, 38; Model Law, Arts. 6, 21(2), 22(1).
} 
and restructuring law are on a continuum. We know that it is notoriously difficult to prove that a debtor is 'insolvent' or 'likely insolvent' or 'viable' at any given moment in time because distress is fluid rather than static. Thus, laws deploy various techniques and proxies for judicial determination that streamline access into formal proceedings - in English law, tools such as the statutory demand ${ }^{126}$ or formal declarations in notice of appointments. ${ }^{127}$ The 'viable business in need of restructuring' may without intervention deteriorate into the 'non-viable' business that ought to be liquidated. Decisions to restructure rather than liquidate (or vice versa) in response to financial distress are governance decisions that confront debtors, creditors, and sometimes courts, on this continuum. The questions that these decisions raise are interwoven: restructuring involves a distribution (or redistribution) of value among stakeholders just as much as liquidation, albeit the methodology (court-based valuation of the debtor's future revenue streams versus market sale) is different. ${ }^{128}$ And, sometimes, because of hybridity, the 'restructure or liquidate' question is conflated within a single proceeding or through a combination of formal proceedings-for example, in English law, a scheme or company voluntary arrangement exit (restructuring) from administration (a proceeding used more often than not to pursue a 'better than liquidation' asset sale). 'Restructure or liquidate' is a governance question that is also directed at how best to maximize value for creditors at the point of intervention. Insolvency proceedings address collective action problems that would harm creditors collectively from maximizing value lower down the demise curve. Pre-insolvency (restructuring) proceedings, too, address holdout and free rider problems ${ }^{129}$ that harm a value-maximizing restructuring higher up the demise curve which may have positive spillover effects (preservation of employment, preservation of long-term supply chain relationships with operating creditors). ${ }^{130}$ Similarly, concerns that managers (or substantial creditors) will take wrong decisions-abusively attempting a restructuring of a non-viable debtor that ought to be liquidated or liquidating a viable debtor that ought to be restructured - are all part of the same continuum. ${ }^{131}$ Insolvency and restructuring law is, therefore, a unified body of law that maps onto the continuum, rather than two discrete bodies of law. One thing bleeds

\footnotetext{
126 Insolvency Act 1986, s. 123(1)(a) (deemed inability to pay debts as portal to compulsory windingup).

127 Ibid., Sch B1, paras. 18 and 29 (statutory declaration by appointer and accompanying statement by insolvency practitioner in notice of appointment of administrator).

128 Tollenaar (2017), p 71 ("[T]here is no principle difference between a restructuring and liquidation. In liquidation the business is sold to a third party for cash. In a restructuring the business is in effect sold to the creditors themselves. Where in a liquidation distributions are made in cash, in a restructuring distributions are made in the form of financial [...] instruments, which taken together represent the entire value of the business').

129 Text to nn. 30-34.

130 See Paterson (2016), pp 699-700, 702, 711, 713, 715, 721 (discussing the role the law might play in steering creditor choice away from a sale and distribution and towards a restructuring that, if successful, could prevent creditors lower down the priority-in-insolvency pecking order, e.g. trade creditors, from suffering losses).

131 Relatedly, in many systems the focus of directors' duties in situations of pre-insolvency distress shifts from owners to creditors because decisions taken by managers in what is often termed the 'zone of insolvency' may have profound implications for creditor entitlements. See e.g. Mevorach (2013).
} 
into the other. A debtor that has a likelihood of insolvency risks breaching loan covenants or triggering events of default and moving swiftly from 'pre-insolvency' to full-blown crisis. Rigid framings that distinguish pre-insolvency (restructuring) proceedings from insolvency proceedings lose sight of this fluidity.

Fourth, given that conditions of distress are fluid and are on a continuum, restructuring cases can arise where debtors will need cross-border assistance and cooperation under existing cross-border insolvency instruments-or new instruments that may be adopted in the future ${ }^{132}$ - to reach a successful outcome. Take, for example, the case of a freestanding UK scheme of arrangement (that is a scheme not combined with some other proceeding) by a debtor on the cusp of a covenant breach that would be a tipping point between 'likely insolvency' and 'insolvency'. What if a dissenting activist hedge fund creditor seeks to leverage its position by threatening or initiating involuntary insolvency or collection proceedings in another country where the debtor has assets? ${ }^{133}$ In that case, cross-border insolvency instruments such as the Model Law offer the prospect of a stay in that country that would prevent the creditor from blowing up the restructuring. ${ }^{134}$ Cross-border insolvency instruments also provide mechanisms for exporting the effects of restructuring plans so that they will bind dissenting and unknown creditors wherever they are situated-again to prevent holdouts from disrupting the outcome. At the moment, there is considerable uncertainty surrounding the treatment of restructuring plans under ordinary commercial conflicts of law rules. ${ }^{135}$ And while the decision of the UK Supreme Court in Rubin v. Eurofinance $S A^{136}$ reminds us that cross-border insolvency has a long way to go before all local courts will enforce foreign restructuring plans on a universalist theory, ${ }^{137}$ UNCITRAL has already taken steps to create a regime for recognition

132 See n. 70 above.
133 A case that provides insight into such commonplace tactics is Re Colt Telecom Group Plc [2002] EWHC 2503 (Ch), [2003] 1 BCLC 290. Holdout behaviour in the sovereign debt context is also instructive. See e.g. Araya (2016).

134 See e.g. Model Law, Arts. 20(1)(a), (b), 21(1)(a), (b).

135 Commercial conflicts regimes such as the recast Brussels Regulation (Regulation (EU) 1215/2012 of the European Parliament and of the Council of 12 December 2012 on jurisdiction and the recognition and enforcement of judgments in civil and commercial matters (recast)) and the Hague Convention of 30 June 2005 on Choice of Courts Agreements exclude 'judicial arrangements, compositions and analogous proceedings' (in the case of the Brussels Regulation) and 'insolvency, composition and analogous matters' (in the case of the Hague Convention). On one view, based on a dovetailing theory, restructuring schemes involving solvent companies fall within these instruments while restructuring schemes involving insolvent companies fall within cross-border insolvency law. On another view, restructuring schemes outside the scope of e.g. the EIR are also excluded by the Brussels/Hague language, fall within a lacuna, and are subject to the vagaries of applicable domestic private international law. The uncertainty, even prior to Brexit, surrounding the legal basis for international jurisdiction and enforcement of UK schemes of arrangement is a case in point. See further Payne (2013); Block-Lieb (2018).

136 Rubin (n. 2).

137 See, in particular, the negative treatment of Cambridge Gas Transp. Corp. v. Official Comm. Of Unsecured Creditors of Navigator Holdings plc [2006] UKPC 26, [2007] 1 AC 508, in which the UK Privy Council enforced an order confirming a chapter 11 reorganization plan on the basis of the need for international cooperation in insolvency, in Rubin (n. 2) and Singularis Holdings Ltd v. PricewaterhouseCoopers [2014] UKPC 36, [2015] AC 1675. The persistence of the Gibbs rule deriving from Antony 
and enforcement of 'insolvency-related judgments' designed to plug the gap. ${ }^{138}$ As things stand, then, cross-border insolvency law is better placed to serve cross-border restructuring efforts. ${ }^{139}$ For practical purposes, it has a first mover advantage.

Let us concede some ground for the moment and admit the possibility of a taxonomy that applies commercial conflicts rules to solvent restructuring proceedings and cross-border insolvency law rules to insolvency proceedings. ${ }^{140}$ This would accommodate normative positions that would object to the use of an 'insolvency' characterization where a debtor is not yet factually insolvent because individual enforcement rights are not yet triggered (debts have neither matured nor accelerated under the terms of the debt contract) and there is, as yet, no general default. ${ }^{141}$ But to overcome current uncertainties, we would need to design a robust international architecture of commercial conflict rules with tailored jurisdictional rules, mechanisms for cross-border injunctive or anti-suit relief to prevent holdouts from blowing up restructurings in foreign jurisdictions, ${ }^{142}$ and tailored rules on the recognition and enforcement of restructuring plans that deal with their special characteristics. ${ }^{143}$ We would also still need a test to manage the borderline between 'solvency' and 'insolvency' that would be hard to craft in a way that accommodates the fluidity of financial distress (e.g. 'likely insolvent' debtors at risk of covenant breach).

\section{Footnote 137 (continued)}

Gibbs \& Sons v. La Société Industrielle et Commerciale des Métaux (1890) LR 25 QBD 399 in English private international law to the effect that the law governing the contract rather than the lex concursus determines the proper discharge of a debt further reinforces the point. See Wight v. Eckhardt Marine GmbH [2003] UKPC 37, [2004] 1 AC 147; In re OJSC International Bank of Azerbaijan, Bakhshiyeva v. Sberbank of Russia et al. [2018] EWHC 792 (Ch), [2018] Bus LR 1270, affd [2018] EWCA Civ 2802, [2019] 2 All ER 713. In In re Agrokor d.d. et al. 591 BR 163 (Bkrtcy SDNY 2018), the United States Bankruptcy Court for the Southern District of New York recognized and enforced a settlement agreement noting (at p 192) that the Gibbs rule 'remains the governing law in England despite its seeming incongruence with the principle of modified universalism espoused by the Model Law and a broad consensus of international insolvency practitioners and jurists'. See also, along similar lines, Ramesh (2017). Divergence over the private international law rules applicable to debt discharge reflects ongoing confusion concerning the application of cross-border insolvency law in the restructuring context as well as contestation around what modified universalism entails. Insofar as Gibbs represents a territorialistic, decentralized approach to cross-border resolution as default, we regard it as unhelpful. We take this point up further in Sect. 5's account of how modified universalism can work the other way around, i.e. as a global centralizing norm flexible enough to accommodate specific concerns.

${ }^{138}$ See n. 70 above.

139 A fortiori from a UK perspective given the additional uncertainties arising from Brexit and the UK's continuing participation in the EIR, the Brussels Regulation or equivalent, multilateral regimes based on mutual recognition.

${ }^{140}$ On one view, this is how EU law is supposed to work (see n. 135).

${ }^{141}$ See text to nn. 14-15, 27-28. See also Tollenaar (2017), p 74. Tollenaar objects to the Directive insofar as it contemplates the use of insolvency law techniques (e.g. a general stay) and rules (e.g. absolute priority) before collective enforcement rights of creditors have arisen.

${ }^{142}$ It is tolerably clear that provisional and protective measures of the sort contemplated by Art. 35 of the Brussels Regulation in ordinary inter partes commercial litigation would not include a comprehensive moratorium on creditor enforcement.

${ }^{143}$ Restructuring plans are more complex than bilateral contract modifications because there are multiple counterparties and inter-creditor implications. It is common also for restructuring plans to contain non-debtor releases-i.e. agreements by creditors to release their claims against third party guarantors. See e.g. Avanti Communications (n. 92), pp 606-607, 615 et seq. 
Fifth, if we posit discrete private international law regimes for statutory contract modification mechanisms and insolvency proceedings with different rules of jurisdiction and recognition, we run into problems of hybridity that, in turn, risk unhelpful fragmentation of jurisdiction in cross-border restructuring. To illustrate, let us consider three types of hybridity. One arises from multi-purpose proceedings, like chapter 11 , in which several outcomes-skinny restructuring, wholesale restructuring, or liquidating sale — can be accomplished in the same proceeding. We introduced this type-call it 'outcome' hybridity-already in Sect. 2. A second arises where more than one domestic law proceeding is combined to achieve a resolutioncall it 'combination' hybridity - for example, in English law, where a scheme or company voluntary arrangement (CVA) may be sheltered within an administration. A third arises where a proceeding can be accessed by solvent or insolvent entities for restructuring. Here, the proceeding may have a single restructuring purpose, but it is accessible to debtors across a range of financial states. UK schemes of arrangement are the obvious example. Call this third type 'financial status' hybridity.

Outcome and financial status hybrids pose a 'generic versus functional' characterization problem. Recall that under the full collectivity theory, ${ }^{144}$ chapter 11 proceedings are ruled 'in' because of the automatic stay and the capacity for a chapter 11 debtor to force modifications on all creditors, while skinny restructurings through a scheme or procédure de financière sauvegarde accélérée are 'out'. And yet, a prepackaged chapter 11 plan that impairs only the finance creditors is functionally the same as a skinny restructuring through a scheme. ${ }^{145}$ If we characterize chapter 11s generically on the basis that chapter 11 is capable of functioning as a fully collective proceeding, then prepackaged 11 s are 'in'. If we characterize chapter 11s functionally on the basis of the actual outcome pursued, then prepackaged 11s should be 'out'. ${ }^{146}$ A functional approach is needed to make a model based on full collectivity work properly, but a functional approach introduces fact sensitivity into what is supposed to be a streamlined process. Faced with an application for recognition, courts would have to sort between skinny restructuring $11 \mathrm{~s}$ and wholesale 11s. A generic approach along the lines of the EIR annexes is preferable because it allows for easy sorting (11s are generically 'in' whatever their outcome) and creates strong lines of precedent (i.e. once courts recognize proceeding $\mathrm{X}$ under the law of country $\mathrm{Y}$ as an insolvency proceeding, there is a reasonable assurance that they will treat that proceeding as eligible for recognition without having to engage in a fact sensitive inquiry). ${ }^{147}$ An outcome hybrid, like a chapter 11 , raises the same issue in a different way for a model based on the separate domains theory that uncouples

\footnotetext{
144 See Sect. 4.1 above.

145 See Eidenmüller (2018a), p 69 (early financial restructuring of a portion of creditors' claims not collective according to the 'full' collectivity theory).

146 It is difficult to understand why the presence of the stay should make any difference to the characterization because in a prepackaged chapter 11 , the debtor benefits from the automatic stay but often continues to pay operating debts as they fall due, i.e. there is as yet no common pool problem.

147 Our contention here is that speed in cross-border insolvency and restructuring is a practical necessity and we would therefore trade off the risk of 'false positives' against the risk of uncertainty as to which private international law rules apply in a given case.
} 
debt restructuring from insolvency law ${ }^{148}$ : pursuit of a worldwide sale outcome ('in'); pursuit of a restructuring outcome—-skinny or otherwise-('out'). Financial status hybrids pose less of a problem for this model as it would exclude all restructurings whether solvent or insolvent. But the full collectivity model distinguishes between proceedings that address a common pool problem and those that do not. By that measure, a financial restructuring via a scheme of all the debts in an insolvent company ${ }^{149}$ that only has financial assets and debts should be 'in'. ${ }^{150}$

'Combination' hybrids pose a different sort of problem: a problem of fragmentation. Consider first the example of a restructuring plan sheltered behind a stayexactly the kind of procedure that the Directive contemplates. ${ }^{151}$ A comprehensive stay that extends to secured creditors is indicative of an insolvency proceeding but a skinny restructuring would be treated as not fully collective according to the full collectivity model and as restructuring rather than insolvency according to the separate domains model. A seamless resolution making use of a combination of procedures would be broken into its constituent parts for purposes of private international law. Worldwide recognition of the stay proceeding would turn on cross-border insolvency law rules. Worldwide recognition of the restructuring proceeding would turn on ordinary commercial conflicts' rules.

Another example of the problem posed by combination hybrids is where a debtor combines a stay-cum-sale proceeding with a restructuring proceeding to achieve a disguised restructuring. ${ }^{152}$ The controversial case of Bluebrook ${ }^{153}$ is illustrative. In Bluebrook a group of debtors proposed schemes of arrangement with its senior lenders that involved a pre-packaged sale of its operating business to a Newco entity sheltered within an administration proceeding. Under this scheme-cum-administration, senior creditors were to receive part of the sale proceeds and were offered equity in the new entity in return for releasing the balance of their claims. Junior creditors offered nothing in the scheme were left with worthless claims against

\footnotetext{
148 See Sect. 4.2 above.

149 Or in a company where general default is triggered under the finance documents by the company taking steps to restructure.

150 The EIR attempts to solve the problem of financial status hybrids by excluding them as a genus: see text to $\mathrm{n}$. 108. However, there is uncertainty concerning whether schemes of arrangement involving either solvent or insolvent companies are also excluded from the Brussels Regulation. If, on one plausible view, only solvent restructurings fall within the Brussels Regulation, the same proceeding would be treated differently under current law depending on whether it involved a solvent or insolvent company. This underscores our point in the text to nn. 139-143 to the effect that it would be unwise to exclude restructuring proceedings from cross-border insolvency law without first devising a specialist international commercial conflicts regime to accommodate them.

151 The UK government's proposed 28-day moratorium for companies that are prospectively insolvent combined with a scheme, CVA, or the proposed new restructuring procedure would also fall into this category. See Department for Business, Energy \& Industrial Strategy, Insolvency and Corporate Governance (n. 44), pp 42-58, 63-74.

152 Paterson (2016), p 709 (discussing how a pre-packaged sale of operating subsidiaries to a new entity in an administration can be twinned with a scheme of arrangement to achieve a debt-equity swap that leaves dissenting or 'out of the money' classes with worthless claims against an insolvent parent company the value of which has been extracted by the sale).

153 Re Bluebrook Ltd [2009] EWHC 2114 (Ch), [2000] BCC 209.
} 
Oldco, an outcome justified on the basis that the junior creditors had no economic interest in the group because the value of the group's assets was less than the value of the senior debt. The restructuring was skinny not wholesale-only finance creditors were affected-and the end result was functionally identical to a whole class cramdown. ${ }^{154}$ By combining the administration stay with a scheme exit, the debtor achieved a result under English law that could have been achieved more straightforwardly in chapter 11. Perhaps, then, a full collectivity model would treat the composite as an insolvency proceeding. However, the point is not free from doubt because it may regard skinny restructurings (the scheme portion in Bluebrook) as 'not fully collective'. ${ }^{155}$ The separate domains model would treat the administration as an insolvency proceeding and the scheme as a restructuring proceeding. Thus, were it to be necessary for the debtor (1) to prevent disruption of the sale by seeking foreign recognition of the administration and a worldwide stay and (2) to seek foreign recognition of the effect of the scheme, different rules would apply to (1) and (2).

Fragmentation has jurisdictional implications. The application of different rules to different pieces of a combination hybrid could mean that different courts (the insolvency-home court and the court selected by contract) would have jurisdiction over those different pieces. Similarly, in countries that maintain an institutional separation between bankruptcy and commercial courts, debtors might well need to seek the assistance of a bankruptcy court with respect to the 'insolvency' piece and a commercial court with respect to the 'restructuring' piece. ${ }^{156}$ This would be an unfortunate way to deal with problems of distress that are on a single continuum. It would make the coordination of cross-border cases more difficult and costlier and potentially allocate cases (or portions of cases) to generalist courts that lack the focused expertise of bankruptcy courts. Cross-border cases in which stakeholders wish to pursue a financial and operational restructuring involving both asset disposals and a confirmed plan would be harder to accomplish.

For all these reasons, a single legal and institutional framework of transnational law that treats insolvency and restructuring law as a unified body of law (call it 'the law of transnational distress') and that covers the entire continuum may be the preferred approach. Although the current international framework of cross-border insolvency law undoubtedly has gaps, ${ }^{157}$ it is the best model we have for streamlining coordination and scrutiny in cross-border cases. Carving some or all pre-insolvency proceedings out of this framework might increase rather than reduce the uncertainty

\footnotetext{
154 Payne (2018), p 140.

155 Text to nn. 112-115.

156 If, for example, skinny restructurings were carved out of the federal jurisdiction of the US bankruptcy court, the restructuring portion of a combination hybrid involving a scheme of New York governed law notes would end up in a state court because (1) there would be no federal subject matter jurisdiction and (2) there is no general federal law governing recognition of foreign judgments. Federal courts can apply state conflicts law where they have diversity or federal question jurisdiction. But absent a basis for federal jurisdiction in chapter 15 , recognition and enforcement of a foreign restructuring plan would be a state court matter. See generally Brand (2012).

157 See generally Mevorach (2018a).
} 
on the fluid borderline between 'solvency' and 'insolvency', and potentially increase coordination costs because of the risk of fragmentation.

\section{Modified Universalism and Pre-insolvency Proceedings}

While earlier in Sect. 3 we described modified universalism in absolute terms, the truth is that modified universalism has been understood in different ways and, notwithstanding its dominance, the nature of modified universalism is still somewhat amorphous and contested. ${ }^{158}$ Modified universalism is often viewed as some form of compromise between universalism and territorialism, ${ }^{159}$ or as an interim solution until the ideal of pure universalism can be achieved. ${ }^{160}$ It has been dubbed a 'thread', a 'term', or a 'trend'. ${ }^{161}$ Nonetheless, it can be observed that modified universalism is evolving as a norm in its own right. ${ }^{162}$ It is not so much a compromise as a realistic, and thus flexible, approach, that can accommodate different business structures, different types of proceeding, different market sizes, different levels of market integration, and new or emerging trends in the field of insolvency. ${ }^{163}$ Modified universalism aims to achieve the goals of insolvency, on a cross-border level, namely to promote a fair and indeed the most efficient solution, considering the positions of all relevant stakeholders wherever located. ${ }^{164}$ It seeks to enable global solutions to multinational default with efficient levels of centralization of insolvency proceedings. ${ }^{165}$ It is becoming a prevalent norm, increasingly followed by countries, institutions tasked with implementation of international instruments and international policy makers.

Moreover, modified universalism may be emerging as customary international law (CIL). ${ }^{166} \mathrm{CIL}$ is a recognized legal source that can fill gaps in international instruments and influence existing instruments. It arises from the general and consistent practice of states, where that practice is based on a belief in the conformity of

\footnotetext{
158 Ibid., p 80.

159 Cf. the 'Internationalist Principle' which was similarly developed as a form of 'workable compromise' between the 'rival principles' of international insolvency. See Fletcher (2005), pp 11, 15.

160 See e.g. Bork (2017), p 28 ('For the time being, exceptions to the principle of universalism [...] must be tolerated, yet there is no need to lose sight of the final goals of global implementation of this principle with as few exceptions as possible'). Compare, however, Pottow (2014), pp 202-204 (suggesting that modified universalism is an independent normative approach, although considered an incremental step towards pure universalism).

161 See e.g. In re HIH Casualty and General Insurance Ltd [2008] UKHL 21, [2008] 1 WLR 852, [7], [30] where the UK court refers to a 'principle rather than a rule', an 'aspiration' and a 'thread'; In re Nortel Networks, Inc, 532 BR 494 (Bankr D Del 2015), p 558 where the US court refers to 'terms such as "universalism",; Rubin (n. 2), [16] where the UK Supreme Court notes that "there has been a trend, but only a trend, to what is called universalism [...]'.

162 See Mevorach (2018a), ch. 3.

163 For a mapping of the different aspects of the modified universalist norm, see Mevorach (2018a), pp 14 et seq.

164 Ibid., pp 15 et seq.

165 Westbrook (2000).

166 This paragraph draws on Mevorach (2018a), ch. 3; Mevorach (2018b).
} 
the practice with international law. Once CIL has become pervasive enough, countries are bound by it regardless of whether they have codified the laws domestically or through treaties. CIL is also responsive to emerging trends in practice. Modified universalism is already quite dominant, and it is also flexible and thus akin to CIL. It can finally transform into CIL to become part of the international insolvency legal order if we no longer aspire to implement pure universalism but instead focus the effort on specifying the modified universalist norm and improving its coverage and reach. Because of its flexibility and wide applicability (as a default system that does not require active adoption), CIL, alongside the further development of instruments such as the Model Law, can also to some extent overcome territorialist biases that still prevail in real-world decision making. ${ }^{167}$

Modified universalism is more advanced in some aspects than it is in others. For example, the norms concerning enterprise groups or regarding banks (in cross-border insolvency/resolution) are at an emergent stage. ${ }^{168}$ Indeed, so is the modified universalist norm as it applies to pre-insolvency proceedings. Modified universalism is, however, pliable and can react to new trends in the market, and the evolution of preventive procedures is one such notable movement. The modified universalist norm is also influenced by developments of international instruments, in the form of soft or hard law (and vice versa, the norm influences the instruments). ${ }^{169}$

As explained in Sect. 3, both the EIR and the Model Law (the key regional/ international instruments of cross-border insolvency) have, to some extent, already adapted to the trend towards pre-insolvency proceedings, which in turn contributes to the development of modified universalism. This response to the pre-insolvency trend in the instruments is, however, not necessarily complete. There is room for further consideration of the type of cross-border solutions that should be employed in such cases. Issues for further consideration flow from the discussion of core features of pre-insolvency proceedings discussed earlier. We briefly indicate below some aspects of cross-border pre-insolvency proceedings that may require flexible accommodation by the modified universalism norm and the instruments linked to it, though we do not suggest that this exposition represents a complete list.

In terms of jurisdiction and the mirroring recognition rule, it was noted in Sect. 3 that modified universalism has largely focused on the notion of the debtor 'home country', which has been developed into the COMI rule in the regional and international instruments. In the typical formal insolvency cases, which involve operational reorganization or liquidation, centralization of a cross-border insolvency process will most efficiently take place at the COMI. 'Forum shopping' to other places should be closely scrutinized to ensure that relocations are not pursued for the

\footnotetext{
167 Such biases include loss aversion, endowment effects, status quo bias, bounded willpower of policy makers, and territorialist short-termism. See Mevorach (2018a), ch. 2.

168 Ibid., p 20. See also the UNCITRAL Model Law on Enterprise Groups adopted in 2019 (n. 70 above).

169 Mevorach (2018a), pp 112-113 (explaining the interaction between modified universalism as an emerging customary international law and the development of cross-border insolvency instruments).
} 
wrong reasons, ${ }^{170}$ and that creditors are on board and the relocation does not contradict their expectations. ${ }^{171}$ In cross-border pre-insolvency proceedings, however, and especially in skinny restructurings, the jurisdiction/recognition rule may be more relaxed at least in the way it is applied in practice. It may be less important to concentrate the proceedings in the place of key operational decisions, and more important to look for a jurisdiction that can effectively implement a restructuring, namely a forum that provides a proceeding exhibiting the core features of pre-insolvency measures discussed earlier. The home of the restructuring, therefore, may not necessarily be at the COMI, ${ }^{172}$ strictly speaking in the sense of where operational decisions were ascertainably made before the need for pre-insolvency proceedings arose.

As explained in Sect. 2, a key aim of pre-insolvency proceedings is to resolve deadlocks and hold-outs. On the international level, this aim can be extended to resolving 'jurisdiction deadlocks' and 'jurisdiction holdouts', where the debtor or relevant creditors attempt to initiate a pre-insolvency proceeding in a place where such a proceeding is available and is likely to provide an effective outcome. Concerns regarding creditors' expectations are also generally less acute. ${ }^{173}$ Subject to safeguards, ordinarily such attempts should be permitted. The presumption should be in favour of the relocation, which may be understood as 'forum choice' (ex post when the debtor is approaching insolvency) in such cases. Furthermore, a full relocation of the COMI may not be required for ascertaining jurisdiction (under the EIR system) and for recognition of the pre-insolvency proceeding as the main proceeding (under the Model Law regime), especially where in the (original) COMI forum a restructuring mechanism is not available. ${ }^{174}$

The reality is that many countries have not yet caught up with global restructuring trends. The case of Ocean Rig provides a good example. ${ }^{175}$ In this case, a group of companies were COMI'd in a country that had no pre-insolvency proceeding

\footnotetext{
170 Abusive forum shopping involves self-serving relocations where the debtor or influential creditors attempt to move to a jurisdiction favourable to them at the expense of the general body of creditors. Ibid., p 198.

${ }^{171}$ In accordance with the understanding of COMI as the place of central administration ascertainable by third parties: see EIR, Art. 3(1); Guide to Enactment, paras. 70-71.

172 See also the new model law for enterprise groups (n. 70 above), which will allow the concentration of proceedings in a planning forum for the purpose of developing and implementing a group insolvency solution at the main (COMI) forum of an enterprise group member which 'is likely to be a necessary and integral participant in that group insolvency solution'.

173 See Sect. 4 above.

174 See Westbrook (2018), pp 1483-1488 (articulating circumstances in which it may be plausible to select a central 'control' court other than the COMI court as the locus of the main proceeding including e.g. where a case cannot be filed in the COMI court or where a filing elsewhere would better serve the interests of stakeholders because of deficiencies in the COMI jurisdiction's insolvency system). See also Mevorach (2018a), p 186.

175 In re Ocean Rig UDW Inc 570 BR 687 (Bkrtcy SDNY 2017). A shareholder, Tally Wiener, objected to recognition and pursued an appeal to the District Court, and a further appeal to the US Court of Appeals for the Second Circuit. Her appeals were dismissed ultimately for lack of standing without the District Court or Second Circuit reviewing the substantive merits of the Bankruptcy Court's COMI determination. See In re Ocean Rig UDW Inc 585 BR 31 (United States District Court, SDNY 2018), affd 764 Fed Appx 46 (2019).
} 
(Marshall Islands). The group's members therefore relocated their COMI and initiated debt restructuring proceedings in the Cayman Islands. The Cayman Islands court appointed joint provisional liquidators to promote schemes of arrangement for the companies. The provisional liquidators then sought recognition of the proceedings in the United States under the Model Law (chapter 15 of the US Bankruptcy Code). Notwithstanding objections, the Bankruptcy Court granted interim relief enabling the provisional liquidators to set up and procure creditor acceptance and court approval of Cayman schemes and subsequently recognized the Cayman proceedings based, in part, on a finding that the debtors' relocation was legitimate in circumstances where the Cayman Islands, unlike the Marshall Islands has a wellestablished system for debt restructuring. ${ }^{176}$ The Bankruptcy Court then went on to enforce the Cayman schemes of arrangement by means of a permanent injunction ${ }^{177}$ — currently the standard approach in the US for giving effect to foreign restructurings. ${ }^{178}$

The EIR rule on jurisdiction is already quite flexible because it does not prohibit debtors from moving their COMIs when insolvency is approaching. The EIR places modest limits on forum shopping providing only that if the registered office of the company was moved within 3 months before the request for opening of insolvency proceedings, the presumption that the COMI is at the registered office will not apply. ${ }^{179}$ The Model Law does not prohibit forum shopping either. The Guide to Enactment is clear that the debtor's COMI may move prior to the commencement of proceedings 'in some instances in close proximity to commencement [...]. ${ }^{180} \mathrm{How}-$ ever, in such circumstances, the Guide states that it is desirable that the receiving court considers more carefully the factors relevant to determining COMI and takes 'account of the debtor's circumstances more broadly'. ${ }^{181}$ In this respect, the Guide notes in particular that 'the test that the centre of main interests is readily ascertainable by third parties may be harder to meet if the move of the centre of main interests occurs in close proximity to the opening of proceedings'. ${ }^{182} \mathrm{We}$ argue that a shift or a choice of forum to pursue a restructuring, where it is done for the benefit

\footnotetext{
176 Ibid., pp 703 ('The Court finds that the Foreign Debtors' COMI shift was done for proper purposes to facilitate a value-maximizing restructuring of the Foreign Debtors' financial debt'), pp 706-707 ('The Court finds that the Foreign Debtors purposefully established the Cayman Islands as their COMI before the Petition Date. The Foreign Debtors' actions in doing so were not taken in bad faith [...]. The evidence establishes that the Foreign Debtors had a legitimate good faith purpose for shifting their COMI from the RMI to the Cayman Islands.').

177 Ibid., p 707. Footnote 7 of Judge Glenn's opinion contemplates this course of action and an order for permanent injunctive relief was entered after a separate hearing. See further In re Ocean Rig UDW Inc, Case No. 17-10736-mg, Order Granting Joint Provisional Liquidators' Motion Pursuant to sections 105(a), 1507, 1509(b)(2)-(3), 1517(d), 1521(a) and 1525(a) of the Bankruptcy Code for an Order Giving Full Force and Effect to Cayman Schemes of Arrangement, 20 September 2017.

178 Avanti Communications (n. 92), pp 615 et seq.; Energy Coal SPA (n. 112). Cf. In re OJSC International Bank of Azerbaijan (n. 137).

179 EIR, Art. 3(1).

${ }^{180}$ Guide to Enactment, para. 148.

181 Ibid.

182 Ibid.
} 
of the creditors as a whole because the new forum provides appropriate tools not available in the original jurisdiction, should be accepted and recognized following careful assessment of the circumstances and reasons for the move consistent with the Guide to Enactment.

A flexible application of rules on jurisdiction/recognition can also be conducive to group cross-border restructurings. New provisions in the EIR ${ }^{183}$ and the UNCITRAL Model Law on Enterprise Groups ${ }^{184}$ allow some flexibility regarding plans for enterprise groups in distress. Such plans may be developed in a coordination proceedings' (under the EIR) which may be 'requested before any court having jurisdiction over the insolvency proceedings of a member of the group', ${ }^{185}$ or (pursuant to the UNCITRAL instrument) in a 'planning proceedings' which is a main proceedings commenced in respect of a group member and in which other members participate. ${ }^{186}$ Under the UNCITRAL Model Law on Enterprise Groups, it will also be possible to avoid opening additional main proceedings in the forums where group members had their COMIs. ${ }^{187}$ These new concepts should be applied, we argue, sufficiently broadly, especially in the context of restructurings.

The pre-insolvency forum should also govern the proceeding based primarily on its laws and procedures, and this should be recognized internationally, even in the face of objections. ${ }^{188}$ Yet, this primary rule of deference to the law of the main forum may not be absolute and the regime may design specific 'carve outs' ${ }^{189}$ Even when a restructuring is usefully centralized, it should be possible to open additional processes pursuant to domestic law where it is efficient or otherwise appropriate to do so-such an approach will comply with the tenets of modified universalism. Additionally, if the restructuring is not in the original COMI forum (because there was a COMI migration), local laws other than the law of the main forum should be taken into account. ${ }^{190}$ International insolvency objectives may also justify giving effect to local protections because of recognized public policies or the need to protect certain parties, including when they actually relied on the local law and can demonstrate that the application of the home country law would contradict their legitimate expectations. ${ }^{191}$ But a centralized process, even when taking place in parallel to additional local processes or accommodating certain local rights, may rely

\footnotetext{
183 EIR, Chapter V.

184 See n. 70 above.

185 EIR, Art. 61(1).

186 Model Law on Enterprise Groups (n. 70), Art. 2.

187 Ibid., Arts. 31-32 (though these provisions are considered more ambitious and hence provided as 'supplemental' in the Model Law on Enterprise Groups).

188 See also Mokal (2017).

189 See Mevorach (2018a), pp 21 et seq.

190 Ibid., pp 22-23 (noting the 'synthetic secondary proceedings' solution developed in the EU regime and the mechanisms for avoiding multiple main and non-main proceedings in the Model Law on Enterprise Groups through the giving of undertakings concerning the application of local laws).

191 Ibid., p 23, referring to Pottow (2014), pp 205 et seq.
} 
on the procedures and tools available in the main restructuring forum and a full importation of the procedures of local regimes may not be necessary. ${ }^{192}$

Indeed, the choice of law (or 'applicable law') norm is generally in a more developing stage compared to the jurisdiction norm of modified universalism. The Model Law does not explicitly address the choice of law problem, nor do the newer instruments developed by UNCITRAL on the enforcement of insolvency-related judgments and the insolvency of enterprise groups. ${ }^{193}$ This gap should be addressed to make the cross-border insolvency framework more complete, and in the course of such deliberations, the implications on pre-insolvency proceedings should be considered. The EIR, on the other hand, already contemplates detailed rules on applicable law, but in future revisions of these rules (alongside the other key provisions on jurisdiction and recognition), more attention can be given to how the rules apply to pre-insolvency proceedings.

The norm regarding relief that should be provided by foreign courts to main proceedings, and its application in instruments, may also require accommodation. Under the Model Law, for example, the key relief granted to foreign main proceedings is a stay of individual actions and execution against the debtors' assets. ${ }^{194}$ This relief is automatic and denying it is allowed only on the basis of the public policy exception. ${ }^{195}$ We noted in Sect. 2, however, that while an automatic stay is a core component of a chapter 11 case, it is an optional measure in other pre-insolvency proceedings, including those contemplated by the Directive. Relief in cross-border insolvency, in particular under the Model Law, which largely relies on relief requests by foreign representatives, may develop to address more accurately the needs of preinsolvency proceedings with international elements. In a restructuring context, recognition of foreign main proceedings may be sought, for example, to extend their binding effects to stakeholders in other jurisdictions. On the other hand, a procedural stay of proceedings and executions, which is currently granted automatically under the Model Law when proceedings are recognized as foreign main proceedings, may not always be required as some restructurings may be negotiated successfully without a need formally to stop creditors' enforcement.

Safeguards in instruments, primarily the public policy exception to recognition and relief (available in both the EIR and the UNCITRAL instruments), or the notion of 'adequate protection' mentioned earlier in Sect. 4, may require additional specification, ${ }^{196}$ so that they can be applied appropriately in a restructuring context. Importantly, modified universalism and instruments that subscribe to the norm may develop to clarify applicable international standards of fairness in restructuring, which if not followed might result in denial of recognition and of cross-border effects. Notions of fairness in restructuring are still developing alongside the

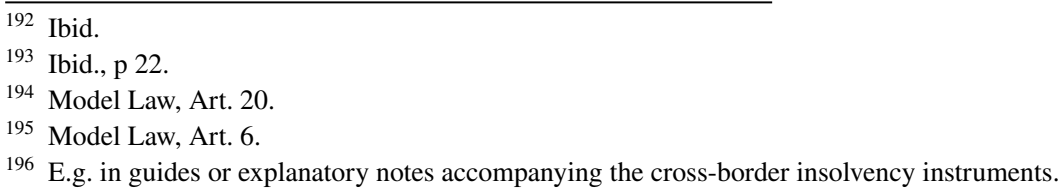


evolution of various preventive procedures. ${ }^{197}$ Instruments such as the Directive and related comparative studies begin to contemplate what fairness may require at the various steps in a restructuring process, ${ }^{198}$ and thus contribute to the emergence of clearer international standards in this area. Indeed, within integrated regions, such as the EU, greater harmonization of pre-insolvency proceedings (which may result from the Directive's implementation) is conducive to the effective application of the EU cross-border insolvency system, based on mutual trust and automatic recognition. Internationally, with lesser harmonization and a more complicated and fluctuating system of trust, the notion of public policy (or adequate protection) may have a more important role, even though the aspiration is to limit its use.

The norm of modified universalism and the instruments governing cross-border insolvency may continue to evolve in the future to accommodate the peculiarities of pre-insolvency proceedings, as experience of handling such processes accumulates. Additional issues to consider in this respect may include, for example, the precise role of the court as guardian of procedural or substantive rights of creditors in various types of pre-insolvency proceedings, in a cross-border context. What we wish to emphasize at this stage is that this flexibility of the modified universalist norm allows it to address the concerns regarding over-inclusivity and alleged lack of nuance of cross-border insolvency law. We can refine and develop the way the norm and the cross-border insolvency instruments apply in different restructuring processes without depriving pre-insolvency proceedings of the benefits of cross-border insolvency law as a sui generis system of private international law.

\section{Conclusion}

The popularity of pre-insolvency proceedings of the types that are nowadays on the rise internationally may continue, or other ways to address companies' financial distress may emerge in the future. Yet, so long as proceedings sit on the spectrum between the pure contractual and the fully formal and possess certain core characteristics of 'state-supplied' processes aimed at avoiding insolvency, there is merit in including them within a unified law of transnational distress for private international law purposes. Building on the existing foundations of international insolvency law is also prudent for we do not yet know what the next wave of restructurings in Europe will look like.

Along the spectrum, proceedings may not be classified neatly within pre-defined boxes and may represent hybrids that can function both as classic pre-insolvency restructuring proceedings and as formal rehabilitation processes. In the so-called twilight zone when debtors are approaching insolvency, insolvency laws, therefore, increasingly attempt to assist firms and their stakeholders by providing incentives and mechanisms for value maximization, at whichever point on the demise curve the intervention occurs. Cross-border insolvency law as a special system of private

\footnotetext{
197 See generally on notions of fairness in restructuring, Paterson (2017).

198 See Stanghellini et al. (2018), ch. II.
} 
international law, governed by the overarching norm of modified universalism, can make these mechanisms work better globally, by minimising coordination and other process costs through a centralized resolution that properly takes into account the interests of all stakeholders involved.

The leading cross-border insolvency instruments, the Model Law and the EIR, which generally follow modified universalism, have responded to the global restructuring trend by favouring the inclusion of debt restructuring proceedings within their scope. Concerns about over-inclusivity of these instruments are, however, important. But as the debate continues, the benefits that cross-border insolvency can provide to pre-insolvency proceedings should not be overlooked. Instead of excluding pre-insolvency proceedings from cross-border insolvency law's scope, we argue that it is preferable to consider how to accommodate the instruments and their underlying (modified universalist) norm so that they serve pre-insolvency proceedings properly. Being a flexible norm, modified universalism can adjust its rules to respond to changing market conditions and to new types of proceedings.

Acknowledgements The authors thank Ted Janger, Stephan Madaus, Sarah Paterson, and Jay Westbrook for comments on earlier drafts. The usual disclaimers apply.

Open Access This article is licensed under a Creative Commons Attribution 4.0 International License, which permits use, sharing, adaptation, distribution and reproduction in any medium or format, as long as you give appropriate credit to the original author(s) and the source, provide a link to the Creative Commons licence, and indicate if changes were made. The images or other third party material in this article are included in the article's Creative Commons licence, unless indicated otherwise in a credit line to the material. If material is not included in the article's Creative Commons licence and your intended use is not permitted by statutory regulation or exceeds the permitted use, you will need to obtain permission directly from the copyright holder. To view a copy of this licence, visit http://creativecommons.org/licen ses/by/4.0/.

\section{References}

American Bankruptcy Institute (2014) Commission to Study Reform of Chapter 11: 2012-2014 Final report and recommendations. http://commission.abi.org/full-report. Accessed 25 Sept 2019

Antonoff R (2013) Out-of-court debt restructuring and the problem of holdouts and free riders. The Metropolitan Corporate Counsel (October 2013), p 17

Araya TM (2016) A decade of sovereign debt litigation: lessons from the NML $v$ Argentina case and the road ahead. Bus Law Int 17(2):83-101

Baird DG (2004) The new face of chapter 11. Am Bankruptcy Inst Law Rev 12:69-99

Block-Lieb S (2018) Reaching to restructure across borders (without over-reaching), even after Brexit. Am Bankruptcy Law J 92:1-51

Bork R (2017) Principles of cross-border insolvency law. Intersentia, Cambridge

Brand RA (2012) Recognition and enforcement of foreign judgments. Federal Judicial Center. https:// Www.fjc.gov/content/recognition-and-enforcement-foreign-judgments-0. Accessed 25 Sept 2019

Connolly DJ (2004) Current issues involving prepackaged and prenegotiated plans. Ann Surv Bankruptcy Law 2

Cousins SD (2002) Chapter 11 asset sales. Del J Corp Law 27:835-849

Dawson A (2018) Modularity in cross-border insolvency. Chi-Kent Law Rev 93:677-710

Eidenmüller H (2017) Contracting for a European insolvency regime. EBOR 18:273-304

Eidenmüller H (2018a) What is an insolvency proceeding? Am Bankruptcy Law J 92:53-72

Eidenmüller H (2018b) Comparative corporate insolvency law. In: Gordon JN, Ringe WG (eds) The Oxford handbook of corporate law and governance. Oxford University Press, Oxford, pp 1003-1036 
Eidenmüller H, van Zwieten K (2015) Restructuring the European business enterprise: the EU Commission recommendation on a new approach to business failure and insolvency. EBOR 16:625-667

Fletcher IF (2005) Insolvency in private international law, 2nd edn. Oxford University Press, Oxford

Gurrea-Martínez A (2018) The future of reorganization procedures in the era of pre-insolvency law. Ibero-American Institute for Law and Finance Working Paper No 6/2018. Singapore Management University School of Law Research Paper No 34/2019. https://papers.ssrn.com/sol3/paper s.cfm?abstract_id=3290366. Accessed 25 Sept 2019

Hargovan A (2010) The source of efficacy for creditors' schemes of arrangement in England, Australia and Singapore. Comp Law 31(7):199-206

Hart O (1995) Firms, contracts, and financial structure. Oxford University Press, Oxford

Heller MA (1998) The tragedy of the anticommons: property in the transition from Marx to markets. Harv Law Rev 111:621-688

Heller MA (2008) The gridlock economy. Basic Books, New York

Hess B et al (2014) European insolvency law-The Heidelberg-Luxembourg-Vienna report on the application of Regulation No 1346/2000/EC on Insolvency Proceedings. Beck, Munich

INSOL Europe (2018) The rise of preventive restructuring schemes: challenges and opportunities. In: Papers from the INSOL Europe academic forum annual conference, Warsaw, Poland, 4-5 October 2017

Jacoby MB (2015) What should judges do in chapter 11? Univ Ill Law Rev 2015(2):571-588

Jacoby MB (2018) Corporate bankruptcy hybridity. Univ Penn Law Rev 166:1715-1747

Jacoby MB, Janger EJ (2014) Ice cube bonds: allocating the price of process in chapter 11 bankruptcy. Yale Law J 123:862-947

Madaus S (2018) Leaving the shadows of US Bankruptcy law: a proposal to divide the realms of insolvency and restructuring law. EBOR 19:615-647

McCormack G (2017) Corporate restructuring law-a second chance for Europe? Eur Law Rev 42:532-561

McCormack G, Wan YW (2018) Transplanting chapter 11 of the US Bankruptcy Code into Singapore's restructuring and insolvency laws: opportunities and challenges. JCLS 19(1):69-104. https://doi.org/10.1080/14735970.2018.1491680

Mevorach I (2013) The role of enterprise principles in shaping management duties at times of crisis. EBOR 14:471-496

Mevorach I (2018a) The future of cross-border insolvency: overcoming biases and closing gaps. Oxford University Press, Oxford

Mevorach I (2018b) Modified universalism as customary international law. Texas Law Rev 96:1403-1436

Mokal R (2017) Shopping and scheming, and the rule in Gibbs. South Square Digest, Mar 2017, 58-63. https://papers.ssrn.com/sol3/papers.cfm?abstract_id=2922237. Accessed 25 Sept 2019

Olivares-Caminal R et al (2016) Debt restructuring, 2nd edn. Oxford University Press, Oxford

Omar PJ (2014) Upstreaming rescue: pre-insolvency proceedings and the European Insolvency Regulation. ICCLR 25(1):19-25

Paterson S (2016) Rethinking corporate bankruptcy theory in the twenty-first century. OJLS 36(4):697-723

Paterson S (2017) Debt restructuring and notions of fairness. MLR 80(4):600-623

Payne J (2013) Cross-border schemes of arrangement and forum shopping. EBOR 14:563-589

Payne J (2014a) Debt restructuring in English law: lessons from the United States and the need for reform. LQR 130:282-305

Payne J (2014b) Schemes of arrangement: theory, structure and operation. Cambridge University Press, Cambridge

Payne J (2018) The role of the court in debt restructuring. CLJ 77:124-150

Pernick NL, Dean GD (2010) Structured chapter 11 dismissals: a viable and growing alternative after asset sales. Am Bankruptcy Inst J 1:58-59

Phelan R, Tama O (2011) The use of DIP financing as a mechanism to control the corporate restructuring process. Tex J Bus Law 44:15-27

Pottow JAE (2014) Beyond carve-outs and toward reliance: a normative framework for cross-border insolvency choice of law. Brook J Corp Fin Com 9:202-225

Ramesh K (2017) The Gibbs principle: a tether on the feet of good forum shopping. SAcLJ 29:42-74

Seife H, Vazquez F (2008) US Courts should continue to grant recognition to schemes of arrangement of solvent insurance. Norton J Bankruptcy Law Pract 17:571-590 
Skeel DA (2004) The past, present and future of debtor-in-possession financing. Cardozo Law Rev 25(5):1905-1934

Stanghellini L et al (2018) Best practices in European restructuring. Wolters Kluwer, Milan

Sutton A, Setchim R (2014) Valuing sponsor support. Br Actuar J 19:404-429. https://doi. org/10.1017/S1357321713000445

Tollenaar NWA (2017) The European Commission's proposal for a directive on preventive restructuring proceedings. Insolv Int 30(5):65-81

Walters AJ (2015) Statutory erosion of secured creditors' rights: some insights from the United Kingdom. Univ Ill Law Rev 2015(2):543-570

Walters AJ (2017) United States' bankruptcy jurisdiction over foreign entities: exorbitant or congruent? JCLS 17(2):367-404. https://doi.org/10.1080/14735970.2017.1299841

Walters AJ (2019) Modified universalisms and the role of local legal culture in the making of crossborder insolvency law. Am Bankruptcy Law J 93:47-110

Wee MS (2017) Whither the scheme of arrangement in Singapore: more chapter 11, less scheme? Conference paper. https://papers.ssrn.com/sol3/papers.cfm?abstract_id=2922956. Accessed 25 Sept 2019

Weil GG, Manges LLP (2012) Weil comparative guide to restructuring procedures 2012. https://businessfinance-restructuring.weil.com/international/weil-comparative-guide-to-restructuring-procedures/. Accessed 25 Sept 2019

Westbrook JL (2000) A global solution to multinational default. Mich Law Rev 98(7):2276-2328

Westbrook JL (2015) Interpretation internationale. Temple Law Rev 87:739-757

Westbrook JL (2018) Global insolvency proceedings for a global market: the universalist system and the choice of a central court. Texas Law Rev 96:1473-1494

Westbrook JL et al (2010) A global view of business insolvency systems. Martinus Nijhoff, Leiden

Woods N (2003) The United States and the international financial institutions: power and influence within the World Bank and IMF. In: Foot R et al (eds) US hegemony and international organizations. Oxford University Press, Oxford, pp 92-114

Publisher's Note Springer Nature remains neutral with regard to jurisdictional claims in published maps and institutional affiliations.

\section{Affiliations}

\section{Irit Mevorach ${ }^{3} \cdot$ Adrian Walters $^{1,2}$}

Irit Mevorach

irit-mevorach@nottingham.ac.uk

1 Ralph L Brill Professor of Law, IIT Chicago-Kent College of Law, Chicago, IL, USA

2 Professor, Centre for Business and Insolvency Law, Nottingham Law School, Nottingham Trent University, Nottingham, UK

3 Professor of International Commercial Law and Co-Director, University of Nottingham Commercial Law Centre, School of Law, University of Nottingham, Nottingham, UK 